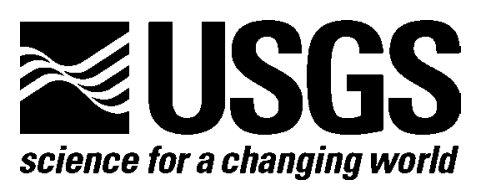

\title{
California State Waters Map Series-Offshore of Gaviota, California
}

By Samuel Y. Johnson, Peter Dartnell, Guy R. Cochrane, Stephen R. Hartwell, Nadine E. Golden, Rikk G. Kvitek, and Clifton W. Davenport

(Samuel Y. Johnson and Susan A. Cochran, editors)

Pamphlet to accompany

Open-File Report 2018-1023

2018

U.S. Department of the Interior

U.S. Geological Survey 


\section{U.S. Department of the Interior \\ RYAN K. ZINKE, Secretary}

\section{U.S. Geological Survey \\ William H, Werkheiser, Deputy Director \\ exercising the authority of the Director}

U.S. Geological Survey, Reston, Virginia: 2018

For more information on the USGS—-the Federal source for science about the Earth, its natural and living resources, natural hazards, and the environment-visit http://www.usgs.gov/ or call 1-888-ASK-USGS (1-888-275-8747).

For an overview of USGS information products, including maps, imagery, and publications, visit http://store.usgs.gov/

To order USGS information products, visit http://store.usgs.gov/.

Any use of trade, firm, or product names is for descriptive purposes only and does not imply endorsement by the U.S. Government.

Although this information product, for the most part, is in the public domain, it also may contain copyrighted materials as noted in the text. Permission to reproduce copyrighted items must be secured from the copyright owner.

Suggested citation:

Johnson, S.Y., Dartnell, P., Cochrane, G.R., Hartwell, S.R., Golden, N.E., Kvitek, R.G., and Davenport, C.W. (S.Y. Johnson and S.A. Cochran, eds.), 2018, California State Waters Map Series-Offshore of Gaviota, California: U.S. Geological Survey Open-File Report 2018-1023, pamphlet 41 p., 9 sheets, scale 1:24,000, https://doi.org/10.3133/ofr20181023.

ISSN 2331-1258 (online) 


\section{Contents}

Preface

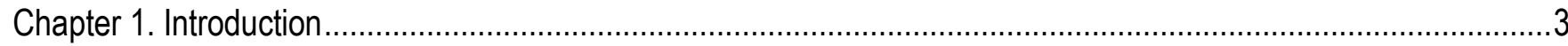

By Samuel Y. Johnson

Regional Setting 3

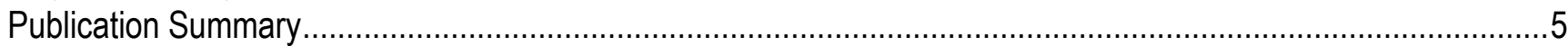

Chapter 2. Bathymetry and Backscatter-Intensity Maps of the Offshore of Gaviota Map Area (Sheets 1, 2, and 3).10

By Peter Dartnell and Rikk G. Kvitek

Chapter 3. Data Integration and Visualization for the Offshore of Gaviota Map Area (Sheet 4). 12

By Peter Dartnell

Chapter 4. Seafloor-Character Map of the Offshore of Gaviota Map Area (Sheet 5)

By Guy R. Cochrane and Stephen R. Hartwell

Chapter 5. Marine Benthic Habitats of the Offshore of Gaviota Map Area (Sheet 6). 18

By Guy R. Cochrane and Stephen R. Hartwell

Map Area Habitats.

Chapter 6. Subsurface Geology and Structure of the Offshore of Gaviota Map Area and the Santa Barbara Channel

Region (Sheets 7 and 8 ) 20

By Samuel Y. Johnson and Stephen R. Hartwell

Data Acquisition. .20

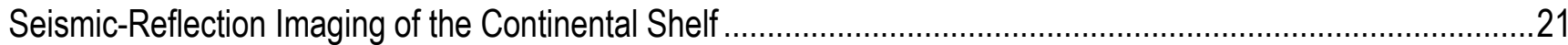

Geologic Structure and Recent Deformation ............................................................................................22

Thickness and Depth to Base of Uppermost Pleistocene and Holocene Deposits .............................................23

Chapter 7. Geologic and Geomorphic Map of the Offshore of Gaviota Map Area (Sheet 9) ...................................25

By Samuel Y. Johnson and Stephen R. Hartwell

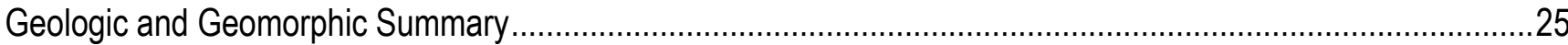

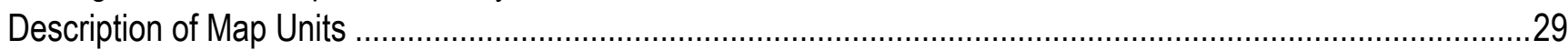

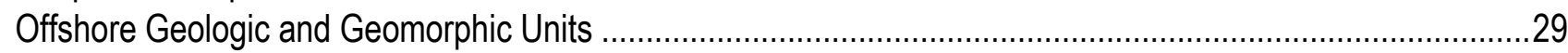

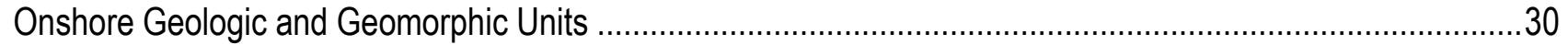

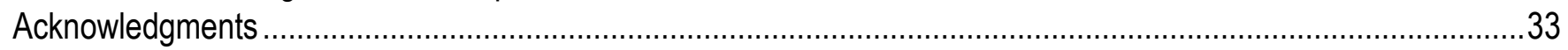

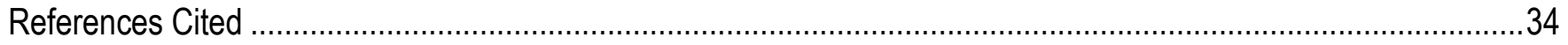

\section{Figures}

Figure 1-1. Physiography of Santa Barbara Channel region........................................................................

Figure 1-2. Coastal geography of Offshore of Gaviota map area.....................................................................

Figure 1-3. Map of Santa Barbara Channel region, showing selected faults and folds ..........................................

Figure 4-1. Detailed view of ground-truth data, showing accuracy-assessment methodology ................................15

\section{Tables}

Table 4-1. Conversion table showing how video observations of primary substrate, secondary substrate, and abiotic seafloor complexity are grouped into seafloor-character-map Classes I, II, and III for use in supervised classification and accuracy assessment in Offshore of Gaviota map area

Table 4-2. Accuracy-assessment statistics for seafloor-character-map classifications in Offshore of Gaviota map area

Table 5-1. Marine benthic habitats from Coastal and Marine Ecological Classification Standard mapped in Offshore of Gaviota map area 
Table 6-1. Area, sediment-thickness, and sediment-volume data for California's State Waters in Santa Barbara Channel region, between Point Conception and Hueneme Canyon areas, as well as in the Offshore of Gaviota map area.

Table 7-1. Areas and relative proportions of offshore geologic map units in Offshore of Gaviota map area

\section{Map Sheets}

Sheet 1. Colored Shaded-Relief Bathymetry, Offshore of Gaviota Map Area, California

By Peter Dartnell and Rikk G. Kvitek

Sheet 2. Shaded-Relief Bathymetry, Offshore of Gaviota Map Area, California

By Peter Dartnell and Rikk G. Kvitek

Sheet 3. Acoustic Backscatter, Offshore of Gaviota Map Area, California

By Peter Dartnell and Rikk G. Kvitek

Sheet 4. Data Integration and Visualization, Offshore of Gaviota Map Area, California

By Peter Dartnell

Sheet 5. Seafloor Character, Offshore of Gaviota Map Area, California

By Stephen R. Hartwell and Guy R. Cochrane

Sheet 6. Marine Benthic Habitats from the Coastal and Marine Ecological Classification Standard, Offshore of Gaviota Map Area, California

By Guy R. Cochrane, Stephen R. Hartwell, and Samuel Y. Johnson

Sheet 7. Seismic-Reflection Profiles, Offshore of Gaviota Map Area, California

By Samuel Y. Johnson and Stephen R. Hartwell

Sheet 8. Local (Offshore of Gaviota Map Area) and Regional (Offshore from Point Conception to Hueneme Canyon) Shallow-Subsurface Geology and Structure, Santa Barbara Channel, California

By Samuel Y. Johnson and Stephen R. Hartwell

Sheet 9. Offshore and Onshore Geology and Geomorphology, Offshore of Gaviota Map Area, California

By Stephen R. Hartwell, Samuel Y. Johnson, and Clifton W. Davenport 


\section{California State Waters Map Series-Offshore of Gaviota, California}

By Samuel Y. Johnson, ${ }^{1}$ Peter Dartnell, ${ }^{1}$ Guy R. Cochrane, ${ }^{1}$ Stephen R. Hartwell, ${ }^{1}$ Nadine E. Golden, ${ }^{1}$ Rikk G. Kvitek, $^{2}$ and Clifton W. Davenport ${ }^{3}$

(Samuel Y. Johnson ${ }^{1}$ and Susan A. Cochran, ${ }^{1}$ editors)

\section{Preface}

In 2007, the California Ocean Protection Council initiated the California Seafloor Mapping Program (CSMP), designed to create a comprehensive seafloor map of high-resolution bathymetry, marine benthic habitats, and geology within California's State Waters. The program supports a large number of coastal-zone- and ocean-management issues, including the California Marine Life Protection Act (MLPA) (California Department of Fish and Wildlife, 2008), which requires information about the distribution of ecosystems as part of the design and proposal process for the establishment of Marine Protected Areas. A focus of CSMP is to map California's State Waters with consistent methods at a consistent scale.

The CSMP approach is to create highly detailed seafloor maps through collection, integration, interpretation, and visualization of swath sonar bathymetric data (the undersea equivalent of satellite remote-sensing data in terrestrial mapping), acoustic backscatter, seafloor video, seafloor photography, high-resolution seismic-reflection profiles, and bottom-sediment sampling data (Johnson and others, 2017). The map products display seafloor morphology and character, identify potential marine benthic habitats, and illustrate both the surficial seafloor geology and shallow subsurface geology. It is emphasized that the more interpretive habitat and geology maps rely on the integration of multiple, new high-resolution datasets and that mapping at small scales would not be possible without such data.

This approach and CSMP planning is based in part on recommendations of the Marine Mapping Planning Workshop (Kvitek and others, 2006), attended by coastal and marine managers and scientists from around the state. That workshop established geographic priorities for a coastal mapping project and identified the need for coverage of "lands" from the shore strand line (defined as Mean Higher High Water; MHHW) out to the 3-nautical-mile (5.6-km) limit of California's State Waters. Unfortunately, surveying the zone from MHHW out to 10-m water depth is not consistently possible using ship-based surveying methods, owing to sea state (for example, waves, wind, or currents), kelp coverage, and shallow rock outcrops. Accordingly, some of the maps presented in this series commonly do not cover the zone from the shore out to 10-m depth; these "no data" zones appear pale gray on most maps.

This map is part of a series of online U.S. Geological Survey (USGS) publications, each of which includes several map sheets, some explanatory text, and a descriptive pamphlet. Each map sheet is published as a PDF file. Geographic information system (GIS) files that contain both ESRI ${ }^{4}$ ArcGIS raster grids (for example, bathymetry, seafloor character) and geotiffs (for example, shaded relief) are also included for each publication. For those who do not own the full suite of ESRI GIS and mapping software, the data can be read using ESRI ArcReader, a free viewer that is available at

\footnotetext{
${ }^{1}$ U.S. Geological Survey

${ }^{2}$ California State University, Monterey Bay, Seafloor Mapping Lab

${ }^{3}$ California Geological Survey

${ }^{4}$ Environmental Systems Research Institute, Inc.
} 
http://www.esri.com/software/arcgis/arcreader/index.html (last accessed March 27, 2016). Web services, which consist of standard implementations of ArcGIS REST Service and OGC GIS Web Service

(WMS), also are available for all published GIS data. All CSMP web services were created using an ArcGIS service definition file, resulting in data layers that are symbolized as shown on the associated map sheets. Both the ArcGIS REST Service and OGC WMS Service include all the individual GIS layers for each map-area publication. Data layers are bundled together in a map-area web service; however, each layer can be symbolized and accessed individually after the web service is ingested into a desktop application or web map. CSMP web services enable users to download and view CSMP data, as well as to easily add CSMP data to their own workflows, using any browser-enabled, standalone or mobile device.

The California Seafloor Mapping Program (CSMP) is a collaborative venture between numerous different federal and state agencies, academia, and the private sector. CSMP partners include the California Coastal Conservancy, the California Ocean Protection Council, the California Department of Fish and Wildlife, the California Geological Survey, California State University at Monterey Bay's Seafloor Mapping Lab, Moss Landing Marine Laboratories Center for Habitat Studies, Fugro Pelagos, Pacific Gas and Electric Company, National Oceanic and Atmospheric Administration (NOAA, including National Ocean Service - Office of Coast Surveys, National Marine Sanctuaries, and National Marine Fisheries Service), U.S. Army Corps of Engineers, the Bureau of Ocean Energy Management, the National Park Service, and the U.S. Geological Survey. 


\title{
Chapter 1. Introduction
}

\author{
By Samuel Y. Johnson
}

\section{Regional Setting}

The map area offshore of Gaviota, California, which is referred to herein as the "Offshore of Gaviota" map area (figs. 1-1, 1-2), lies within the western Santa Barbara Channel region of the Southern California Bight (see, for example, Lee and Normark, 2009). This geologically complex region forms a major biogeographic transition zone, separating the cold-temperate Oregonian province north of Point Conception from the warm-temperate California province to the south (Briggs, 1974). Within this region, the offshore part of the map area lies south of the steep south flank of the Santa Ynez Mountains. The crest of the range, which lies about $4 \mathrm{~km}$ north of the shoreline, has a maximum elevation of about $760 \mathrm{~m}$.

Gaviota (Spanish for "seagull") is an unincorporated community that has a sparse population (less than 100), and the coastal zone is largely open space that is locally used for cattle grazing. The Union Pacific railroad tracks extend westward along the coast through the entire map area, within a few hundred meters of the shoreline. Highway 101 crosses the eastern part of the map area, also along the coast, then turns north (inland) and travels through Cañada de la Gaviota and Gaviota Pass en route to Buellton (fig. 1-1). Gaviota State Park lies at the mouth of Cañada de la Gaviota (fig. 1-2). West of Gaviota, the onland coastal zone is occupied by the Hollister Ranch, a privately owned, gated community that has no public access.

The map area has a long history of petroleum exploration and development. Several offshore gas fields were discovered and were developed by onshore directional drilling in the 1950s and 1960s (Yerkes and others, 1969; Galloway, 1998). Three offshore petroleum platforms were installed in adjacent federal waters in 1976 (platform "Honda") and 1989 (platforms "Heritage" and "Harmony"). Local offshore and onshore operations were serviced for more than a century by the Gaviota marine terminal (fig. 1-2), a site that has been variably used for more than a century as an asphalt refinery, oil refinery, crude-oil marine terminal, crude-oil-pipeline terminal, and other operations (County of Santa Barbara, Planning and Development, Energy Division, 2016). The marine terminal is currently being decommissioned and will be abandoned in an intended transition to public open space.

The Offshore of Gaviota map area lies in the western-central part of the Santa Barbara littoral cell (fig. 1-1), which is characterized by west-to-east transport of sediment from Point Arguello on the northwest to Hueneme and Mugu Canyons on the southeast (see, for example, Griggs and others, 2005; Hapke and others, 2006). Sediment supply to the western and central part of the littoral cell is mainly from relatively small coastal watersheds, which have an estimated cumulative annual sediment flux of 640,000 tons/yr between Point Arguello and the Ventura River (fig. 1-1; see also, Warrick and Farnsworth, 2009). Consistent with this estimate, Griggs and others (2005) reported dredging records from the harbor at Santa Barbara that range from about 160,000 to 800,000 tons/yr, averaging 400,000 tons/yr, providing a proxy for longshore drift rates.

Cañada de la Gaviota is the largest coastal watershed (about $52 \mathrm{~km}^{2}$; Warrick and Mertes, 2009) between the Ventura River and Point Conception, and it is inferred to be the largest sediment source in this zone. Smaller watersheds in the Offshore of Gaviota map area include Cañada de la Llegua, Arroyo el Bulito, Cañada de Santa Anita, Cañada de Alegria, Cañada del Agua Caliente, Cañada del Barro, Cañada del Leon, Cañada San Onofre, and many others (fig. 1-2). The much larger Santa Ynez and Santa Maria Rivers, the mouths of which are 60 to $100 \mathrm{~km}$ northwest of the map area (following the coast; fig. 1-1), are not considered to be significant sediment sources because Point Conception and Point Arguello (fig. 1-1) provide obstacles to downcoast, southeastward sediment transport and also because, at present, much of their sediment load is trapped in dams (Griggs and others, 2005). 
Coastal-watershed discharge and sediment load are highly variable, characterized by brief large events during major winter storms and long periods of low (or no) flow and minimal sediment load between storms. In recent (recorded) history, the majority of high-discharge, high-sediment-flux events have been associated with El Niño phases of the El Niño-Southern Oscillation (ENSO) climatic pattern (Warrick and Farnsworth, 2009).

Narrow beaches that have thin sediment (sand and pebbles) cover, backed by low (10- to 20-mhigh) cliffs that are capped by a narrow coastal terrace, characterize the shoreline in the Offshore of Gaviota map area. Beaches are subject to wave erosion during winter storms, followed by gradual sediment recovery or accretion in the late spring, summer, and fall months during the gentler wave climate. Hapke and others (2006, their fig. 33) suggested that essentially no net change (accretion or erosion) to the beaches in the map area has occurred in the long term (since the mid- to late-1800s); however, the beaches have been eroding at an average rate of about $0.6 \mathrm{~m} / \mathrm{yr}$ in the short term (1976 to 1998). Hapke and Reid (2007, their fig. 29) also indicated that coastal bluffs in the map area are eroding at a rate of about $0.2 \mathrm{~m} / \mathrm{yr}$. As with stream discharge and sediment flux, coastal erosion has been most acute during El Niño phases of the ENSO climatic pattern.

The offshore Gaviota sediment bar (fig. 1-2), which extends southwestward for about $9 \mathrm{~km}$ from the mouth of Cañada de la Gaviota to the shelf break, is as wide as $2 \mathrm{~km}$, and it is by far the largest shore-attached sediment bar in the Santa Barbara Channel. The bar, which faces southeast, has a relatively flat $\left(\sim 1.4^{\circ}\right)$ top that extends to water depths of $60 \mathrm{~m}$. The front of the bar has failed intermittently, and the steep (as much as $5^{\circ}$ ) bar front is bounded by an apron of coalescing mass-flow lobes.

Shelf width in the Offshore of Gaviota map area ranges from about 4.3 to $4.7 \mathrm{~km}$, and shelf slopes average about $1.0^{\circ}$ to $1.2^{\circ}$ but are highly variable because of the presence of the large Gaviota sediment bar. The shelf is underlain by bedrock and variable amounts ( 0 to as much as $36 \mathrm{~m}$ in the Gaviota bar) of upper Quaternary sediments deposited as sea level fluctuated in the late Pleistocene (see sheet 9 of this report; see also, Slater and others, 2002; Draut and others, 2009; Sommerfield and others, 2009).

This part of the Southern California Bight is somewhat protected from large Pacific swells from the north and northwest by Point Conception and from south and southwest swells by offshore islands and banks (O'Reilly and Guza, 1993; Cudaback and others, 2005). Fair-weather wave base is typically shallower than 20-m water depth, but winter storms are capable of resuspending fine-grained sediments in $30 \mathrm{~m}$ of water (Xu and Noble, 2009, their table 7), and so shallow (depths of 30 to $60 \mathrm{~m}$ ) shelf sediments in the map area probably are remobilized on an annual basis. As with sediment discharge from rivers, the largest wave events and the highest sediment-transport rates on the shelf are typically associated with the El Niño phases of the ENSO climatic pattern (Xu and Noble, 2009).

Within the map area, the trend of the shelf break changes from about $276^{\circ}$ to $236^{\circ}$ azimuth over a distance of about $12 \mathrm{~km}$, and it ranges in depth from about $91 \mathrm{~m}$ to as shallow as 62 to $73 \mathrm{~m}$ where significant shelf-break and upper-slope failure and landsliding has apparently occurred. Below the shelf break in the eastern part of the map area, the upper slope is relatively smooth, and slopes it offshore as much as $6^{\circ}$. The shelf break in the western part of the map area is notably embayed by the heads of three large (150- to 300-m-wide) channels that have been referred to as "the Gaviota Canyons" (Fischer and Cherven, 1998) or as "Drake Canyon," "Sacate Canyon," and "Alegria Canyon" (Eichhubl and others, 2002).

Seafloor habitats in the broad Santa Barbara Channel region consist of significant amounts of soft, unconsolidated sediment interspersed with isolated areas of rocky habitat that support kelp-forest communities in the nearshore and rocky-reef communities in deeper water. The potential marine benthic habitat types mapped in the Offshore of Gaviota map area are directly related to its Quaternary geologic history, geomorphology, and active sedimentary processes. These potential habitats lie primarily within 
the Shelf (continental shelf) but also partly within the Flank (basin flank or continental slope) megahabitats of Greene and others (2007). The fairly homogeneous seafloor of sediment and low-relief bedrock provides characteristic habitat for groundfish, crabs, shrimp, and other marine benthic organisms, and the bedrock outcrops are potential benthic habitats for rockfish (Sebastes spp.) and other groundfish that forage and seek refuge in such habitats. In addition, several areas of smooth sediment that form nearshore terraces that have relatively steep, smooth fronts may provide interfaces attractive to certain species of groundfish. Below the steep shelf break, within the basin flank or continental slope megahabitat, the seafloor is composed of soft, unconsolidated sediment interrupted by the heads of several submarine canyons and rills, some bedrock exposures, and small carbonate mounds associated with asphalt mounds and pockmarks. The steep shelf break and carbonate mounds are also good potential habitat for rockfish. The map area includes the relatively small $\left(5.2 \mathrm{~km}^{2}\right)$ Kashtayit State Marine Conservation Area (fig. 1-2), which largely occupies the inner part of the Gaviota sediment bar.

The Offshore of Gaviota map area is in the southern part of the Western Transverse Ranges geologic province, which is north of the California Continental Borderland ${ }^{5}$ (Fisher and others, 2009). Significant clockwise rotation - at least $90^{\circ}$ — since the early Miocene has been proposed for the Western Transverse Ranges province (Luyendyk and others, 1980; Hornafius and others, 1986; Nicholson and others, 1994), and this region is presently undergoing north-south shortening (see, for example, Larson and Webb, 1992; Marshall and others, 2013). Regional cross sections (Tennyson and Kropp, 1998; Redin and others, 2005) have suggested that the south flank of the Santa Ynez Mountains is a large, south-dipping homocline that overlies the north-dipping Pitas Point-North Channel Fault system (fig. 1-3; see also, Sorlien and Nicholson, 2015). The homoclinal section extends upward from the Cretaceous strata exposed high in the mountains to the Pliocene strata beneath the continental shelf, encountered at shallow depths in offshore wells. Smaller folds (see sheets 7, 8,9) related to local faulting are superimposed on the regional homocline, including the 17-km-long Molino Anticline and the 22-km-long Government Point Syncline (see sheets 8, 9).

Coastal cliffs mainly consist of fine-grained, folded strata of the Miocene Monterey Formation and the upper Miocene and lower Pliocene Sisquoc Formation (Dibblee, 1988a,b). Estimated rates of shoreline uplift that are based on the elevations of late Quaternary marine terraces are highly variable, ranging from about 0.25 to $1.8 \mathrm{~mm} / \mathrm{yr}$ (Muhs and others, 1992; Rockwell and others, 1992; Metcalf, 1994; Duvall and others, 2004; Gurrola and others, 2014).

\section{Publication Summary}

This publication about the Offshore of Gaviota map area includes nine map sheets that contain explanatory text, in addition to this descriptive pamphlet and a data catalog of geographic information system (GIS) files. Sheets 1, 2, and 3 combine data from three different sonar surveys to generate comprehensive high-resolution bathymetry and acoustic-backscatter coverage of the map area. These data reveal a range of physiographic features (highlighted in the perspective views on sheet 4) such as the flat, sediment-covered Santa Barbara shelf interspersed with tectonically controlled bedrock uplifts and coarse-grained deltas and sediment lobes associated with coastal watersheds. To validate the geological and biological interpretations of the sonar data shown on sheets 1,2, and 3, the U.S. Geological Survey towed a camera sled over specific offshore locations, collecting both video and photographic imagery; this "ground-truth" surveying imagery is available at Golden and Cochrane (2013). Sheet 5 is a "seafloor character" map, which classifies the seafloor on the basis of depth, slope, rugosity (ruggedness), and backscatter intensity and which is further informed by the ground-truthsurvey imagery. Sheet 6 is a map of "potential habitats," which are delineated on the basis of substrate

\footnotetext{
${ }^{5}$ The California Continental Borderland is defined as the complex continental margin that extends from Point Conception south into northern Baja California.
} 
type, geomorphology, seafloor process, or other attributes that may provide a habitat for a specific species or assemblage of organisms. Sheet 7 compiles representative seismic-reflection profiles from the map area, providing information on the subsurface stratigraphy and structure of the map area. Sheet 8 shows the distribution and thickness of young sediment (deposited over the last about 21,000 years, during the most recent sea-level rise) in both the map area and the larger Santa Barbara Channel region (offshore from Point Conception to Hueneme Canyon), interpreted on the basis of the seismic-reflection data. Sheet 9 is a geologic map that merges onshore geologic mapping (compiled from existing maps by the California Geological Survey) and new offshore geologic mapping that is based on integration of high-resolution bathymetry and backscatter imagery (sheets 1,2,3), seafloor-sediment and rock samples (Reid and others, 2006), digital camera and video imagery (Golden and Cochrane, 2013), and highresolution seismic-reflection profiles (sheet 7).

The information provided by the map sheets, pamphlet, and data catalog have a broad range of applications (Johnson and others, 2017). High-resolution bathymetry, acoustic backscatter, ground-truthsurveying imagery, and habitat mapping all contribute to habitat characterization and ecosystem-based management by providing essential data for delineation of marine protected areas and ecosystem restoration. Many of the maps provide high-resolution baselines that will be critical for monitoring environmental change associated with climate change, coastal development, or other forcings. Highresolution bathymetry is a critical component for modeling coastal flooding caused by storms and tsunamis, as well as inundation associated with longer term sea-level rise. Seismic-reflection and bathymetric data help characterize earthquake and tsunami sources, critical for natural-hazard assessments of coastal zones. Information on sediment distribution and thickness is essential to the understanding of local and regional sediment transport, as well as the development of regional sedimentmanagement plans. In addition, siting of any new offshore infrastructure (for example, pipelines, cables, or renewable-energy facilities) will depend on new high-resolution mapping. Finally, this mapping will both stimulate and enable new scientific research and also raise public awareness of, and education about, coastal environments and issues. 


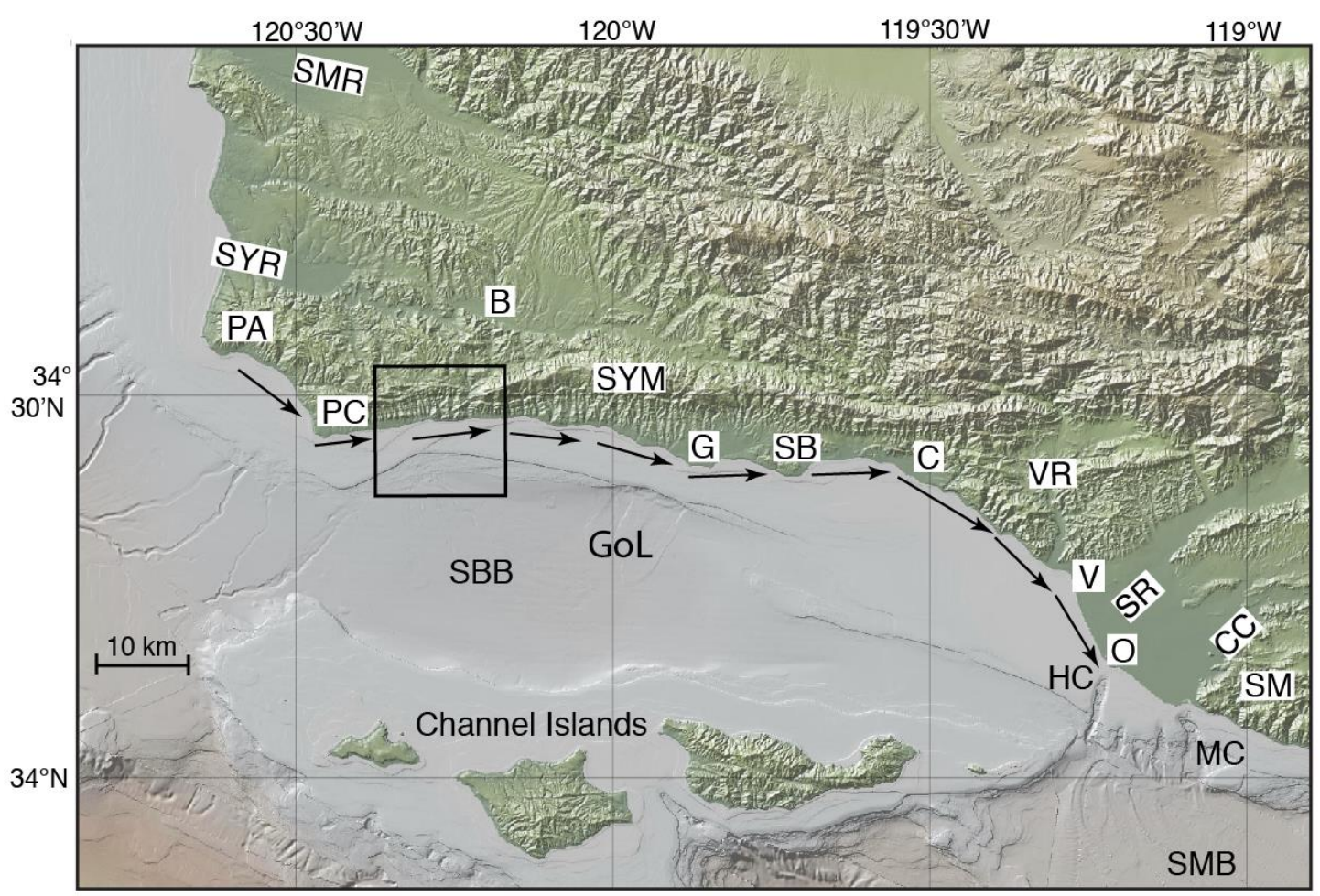

Figure 1-1. Physiography of Santa Barbara Channel region. Box shows Offshore of Gaviota map area. Arrows show direction of sediment transport in Santa Barbara littoral cell, which extends from Point Arguello (PA) to Hueneme Canyon ( $\mathrm{HC}$ ) and Mugu Canyon (MC). Other abbreviations: B, Buellton; C, Carpinteria; CC, Calleguas Creek; G, Goleta; GoL, Goleta landslide complex; O, Oxnard; PC, Point Conception; SB, Santa Barbara; SBB, Santa Barbara Basin; SM, Santa Monica Mountains; SMB, Santa Monica Basin; SMR, Santa Maria River; SR, Santa Clara River; SYM, Santa Ynez Mountains; SYR, Santa Ynez River; V, Ventura; VR, Ventura River. 


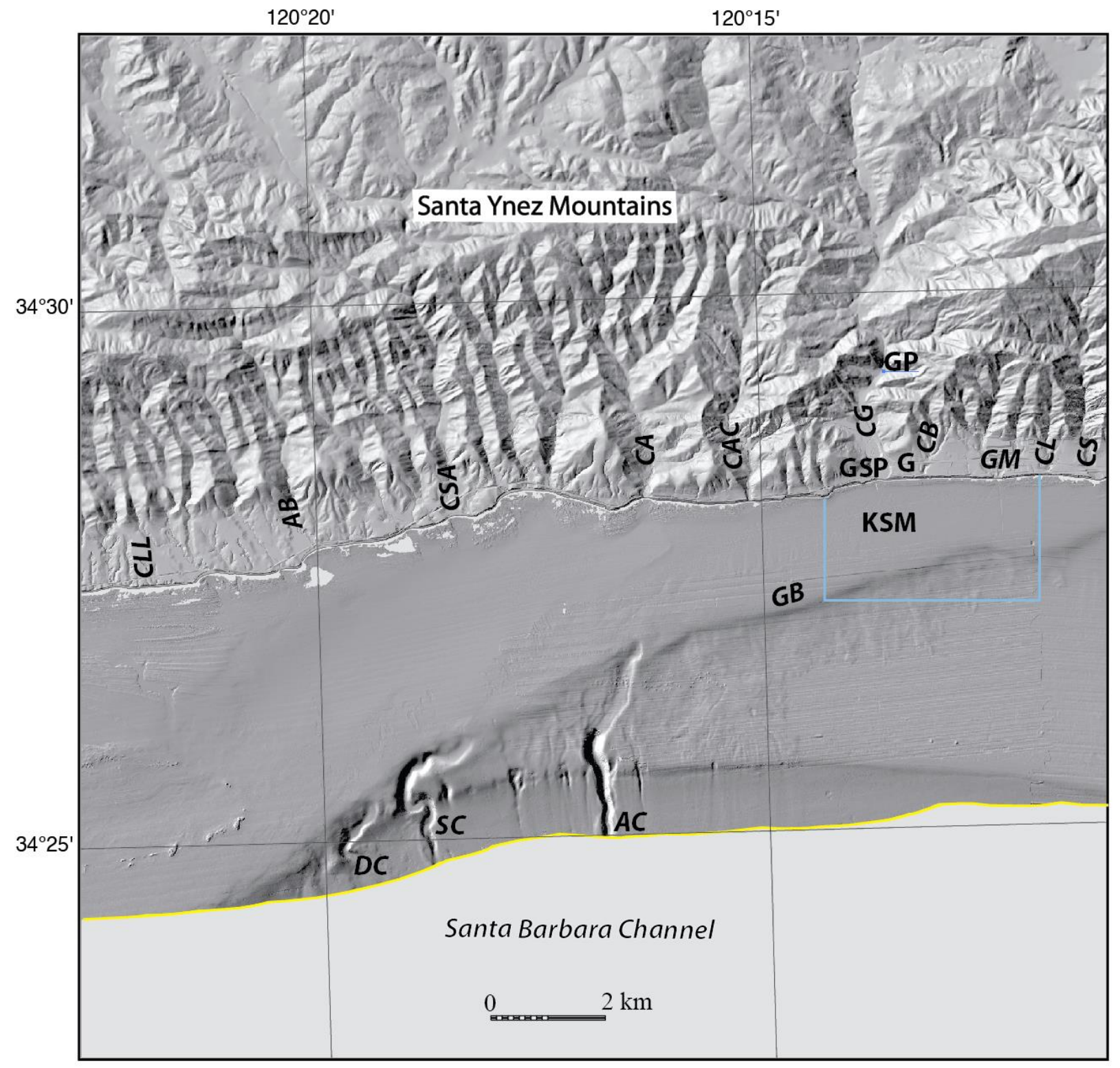

Figure 1-2. Coastal geography of Offshore of Gaviota map area. Yellow line shows 3-nautical-mile limit of California's State Waters. Blue line shows boundary of Kashtayit State Marine Conservation Area (KSM). Other abbreviations: AB, Arroyo el Bulito; AC, "Alegria Canyon;" CA, Cañada de Alegria; CAC, Cañada del Agua Caliente; CB, Cañada del Barro; CG, Cañada de la Gaviota; CL, Cañada del Leon; CLL, Cañada de la Llegua; CS, Cañada San Onofre; CSA, Cañada de Santa Anita; DC, "Drake Canyon;" G, Gaviota; GB, Gaviota sediment bar; GM, Gaviota marine terminal; GP, Gaviota Pass; GSP, Gaviota State Park; SC, "Sacate Canyon." 


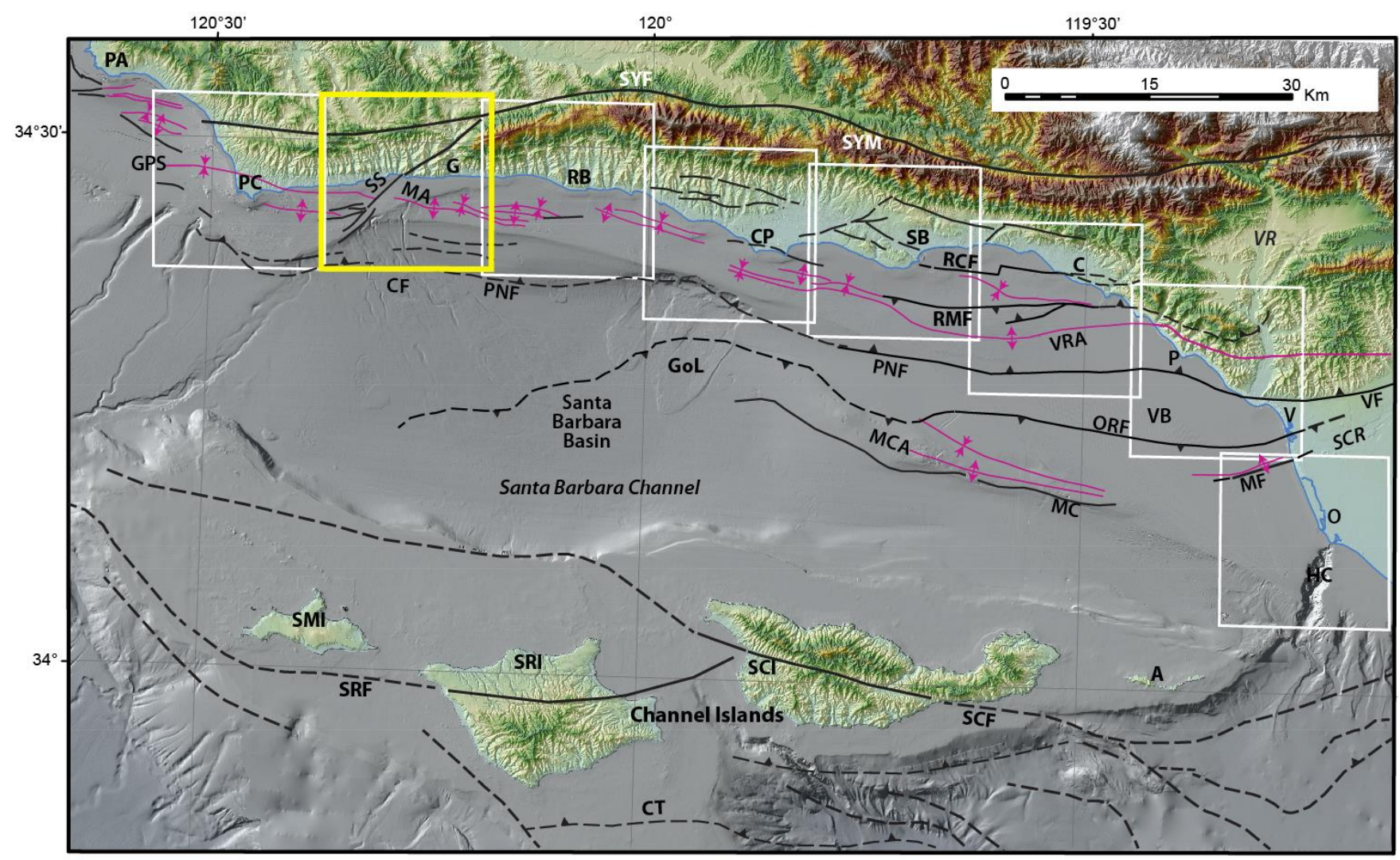

Figure 1-3. Map of Santa Barbara Channel region, showing selected faults and folds. Black lines show faults (solid where location is known; dashed where location is approximate or inferred); barbs on faults show thrust faults (barbs on upper plate); locations of blind Pitas Point-North Channel Fault (PNF) and Oak Ridge Thrust Fault (ORF) systems are projected vertically from tips of faults. Magenta lines show folds (solid where location is known; diverging arrows show anticlines; converging arrows show synclines. Yellow box shows outline of Offshore of Gaviota map area. White boxes show outlines of maps and datasets published by U.S. Geological Survey's California Seafloor Mapping Program (CSMP), listed from east to west (map area names shown in brackets): Johnson and others, 2012 [Hueneme Canyon], 2013b [Ventura], 2013c [Carpinteria], 2013a [Santa Barbara], 2014 [Coal Oil Point], 2015 [Refugio Beach], 2018 [Point Conception]. Fault locations are from Sorlien and others (2006), Chaytor and others (2008), Minor and others (2009), and U.S. Geological Survey and California Geological Survey (2016), as well as from CSMP publications listed above. Other abbreviations: A, Anacapa Island; C, Carpinteria; CF, Conception fan; CP, Coal Oil Point; CT, Channel Islands Thrust Fault; G, Gaviota; GoL, Goleta landslide complex; GPS, Government Point Syncline; HC, Hueneme Canyon; MA, Molino Anticline; MC, Mid-Channel Fault; MCA, Mid-Channel Anticline; MF, Montalvo Fault; O, Oxnard; P, Pitas Point; PA, Point Arguello; PC, Point Conception; RB, Refugio Beach; RCF, Rincon Creek Fault; RMF, Red Mountain Fault; SB, Santa Barbara; SCF, Santa Cruz Island Fault; SCI, Santa Cruz Island; SCR, Santa Clara River; SMI, San Miguel Island; SRF, Santa Rosa Island Fault; SRI, Santa Rosa Island; SS, south strand of Santa Ynez Fault; SYF, Santa Ynez Fault; SYM, Santa Ynez Mountains; V, Ventura; VB, Ventura Basin; VF, Ventura Fault; VR, Ventura River; VRA, Ventura Avenue-Rincon-South Ellwood Anticline. 


\title{
Chapter 2. Bathymetry and Backscatter-Intensity Maps of the Offshore of Gaviota Map Area (Sheets 1, 2, and 3)
}

\author{
By Peter Dartnell and Rikk G. Kvitek
}

The colored shaded-relief bathymetry (sheet 1), the shaded-relief bathymetry (sheet 2), and the acoustic-backscatter (sheet 3) maps of the Offshore of Gaviota map area in southern California were generated from bathymetry and backscatter data collected by the U.S. Geological Survey (USGS) and by Fugro Pelagos (fig. 1 on sheets 1, 2, 3) in 2007 and 2008, using a combination of 400-kHz Reson 7125, 240-kHz Reson 8101, and 100-kHz Reson 8111 multibeam echosounders, as well as a 234-kHz SEA SWATHplus bathymetric sidescan-sonar system. In addition, bathymetric- and topographic-lidar data was collected in the nearshore and coastal areas by the U.S. Army Corps of Engineers (USACE) Joint Lidar Bathymetry Technical Center of Expertise in 2009 and 2010. These mapping missions combined to provide continuous bathymetry (sheets 1,2 ) from the shoreline to the 3-nautical-mile limit of California's State Waters, as well as acoustic-backscatter data (sheet 3) from about the 10-m isobath to beyond the 3-nautical-mile limit.

During the USGS mapping missions, GPS data with real-time-kinematic corrections were combined with measurements of vessel motion (heave, pitch, and roll) in a CodaOctopus F190 attitudeand-position system to produce a high-precision vessel-attitude packet. This packet was transmitted to the acquisition software in real time and combined with instantaneous sound-velocity measurements at the transducer head before each ping. The returned samples were projected to the seafloor using a raytracing algorithm that works with previously measured sound-velocity profiles. Statistical filters were applied to discriminate seafloor returns (soundings and backscatter intensity) from unintended targets in the water column. Further editing of the USGS 2007 bathymetric-sounding data was completed in 2016, and the final soundings were converted into a 2-m-resolution bathymetric-surface-model grid. The backscatter data were postprocessed (also in 2016) using SonarWiz software that normalizes for timevarying signal loss and beam-directivity differences. Thus, the raw 16-bit backscatter data were gainnormalized to enhance the backscatter of the SWATHplus system. The data were exported in Imagine format, imported into a geographic information system (GIS), and converted to a GRID at 2-m resolution.

During the Fugro Pelagos mapping missions, an Applanix POS-MV (Position and Orientation System for Marine Vessels) was used to accurately position the vessels during data collection, and it also accounted for vessel motion such as heave, pitch, and roll, with navigational input from GPS receivers. Smoothed Best Estimated Trajectory (SBET) files were postprocessed from logged POS-MV files. Sound-velocity profiles were collected with an Applied Microsystems (AM) SVPlus sound velocimeter. Soundings were corrected for vessel motion using the Applanix POS-MV data, for variations in water-column sound velocity using the AM SVPlus data, and for variations in water height (tides) and heave using the postprocessed SBET data (California State University, Monterey Bay, Seafloor Mapping Lab, 2016). The Reson backscatter data were postprocessed using Geocoder software. The backscatter intensities were radiometrically corrected (including despeckling and angle-varying gain adjustments), and the position of each acoustic sample was geometrically corrected for slant range on a line-by-line basis. After the lines were corrected, they were mosaicked into 0.5-m resolution images (California State University, Monterey Bay, Seafloor Mapping Lab, 2016). The mosaics were then exported as georeferenced TIFF images, imported into a GIS, and converted to GRIDs at 2-m resolution.

Nearshore bathymetric-lidar data and acoustic-bathymetric data from within California's State Waters were merged together as part of the 2013 National Oceanic and Atmospheric Administration (NOAA) Coastal California TopoBathy Merge Project (National Oceanic and Atmospheric Administration, 2013). Merged bathymetry data from within the Offshore of Gaviota map area were 
downloaded from this dataset and resampled to 2-m spatial resolution, then the reprocessed 2007 USGS bathymetry data was incorporated into the downloaded data. An illumination having an azimuth of $300^{\circ}$ and from $45^{\circ}$ above the horizon was then applied to the new bathymetric surface to create the shadedrelief imagery (sheets 1,2 ). In addition, a "rainbow" color ramp was applied to the bathymetry data for sheet 1, using reds to represent shallower depths, and blueish greens (and in deeper submarine canyons, purples) to represent greater depths. This colored bathymetry surface was draped over the shaded-relief imagery at 60-percent transparency to create a colored shaded-relief map (sheet 1). Note that the ripple patterns and parallel lines that are apparent within the map area are data-collection and -processing artifacts. These various artifacts are made obvious by the hillshading process.

Bathymetric contours (sheets 1, 2, 3, 5, 6,9) were generated at 10-m intervals from a modified 2m-resolution bathymetric surface. The most continuous contour segments were preserved; smaller segments and isolated island polygons were excluded from the final output. The contours were smoothed using a polynomial approximation with exponential kernel algorithm and a tolerance value of $60 \mathrm{~m}$. The contours were then clipped to the boundary of the map area.

The acoustic-backscatter imagery from each different mapping system and processing method were merged into their own individual grids. These individual grids, which cover different areas, were displayed in a GIS to create a composite acoustic-backscatter map (sheet 3). On the map, brighter tones indicate higher backscatter intensity, and darker tones indicate lower backscatter intensity. The intensity represents a complex interaction between the acoustic pulse and the seafloor, as well as characteristics within the shallow subsurface, providing a general indication of seafloor texture and composition. Backscatter intensity depends on the acoustic source level; the frequency used to image the seafloor; the grazing angle; the composition and character of the seafloor, including grain size, water content, bulk density, and seafloor roughness; and some biological cover. Harder and rougher bottom types such as rocky outcrops or coarse sediment typically return stronger intensities (high backscatter, lighter tones), whereas softer bottom types such as fine sediment return weaker intensities (low backscatter, darker tones). Ripple patterns and straight lines in some parts of the map area are data-collection and -processing artifacts.

The onshore-area image was generated by applying an illumination having an azimuth of $300^{\circ}$ and from $45^{\circ}$ above the horizon to 2-m-resolution topographic-lidar data from National Oceanic and Atmospheric Administration Office for Coastal Management's Digital Coast (available at http://www.csc.noaa.gov/digitalcoast/data/coastallidar/) and to 10-m-resolution topographic-lidar data from the U.S. Geological Survey's National Elevation Dataset (available at http://ned.usgs.gov/). 


\title{
Chapter 3. Data Integration and Visualization for the Offshore of Gaviota Map Area (Sheet 4)
}

\author{
By Peter Dartnell
}

Mapping California's State Waters has produced a vast amount of acoustic and visual data, including bathymetry, acoustic backscatter, seismic-reflection profiles, and seafloor video and photography. These data are used by researchers to develop maps, reports, and other tools to assist in the coastal and marine spatial-planning capability of coastal-zone managers and other stakeholders. For example, seafloor-character (sheet 5), habitat (sheet 6), and geologic (sheet 9) maps of the Offshore of Gaviota map area may be used to assist in the designation of Marine Protected Areas, as well as in their monitoring. These maps and reports also help to analyze environmental change owing to sea-level rise and coastal development, to model and predict sediment and contaminant budgets and transport, to site offshore infrastructure, and to assess tsunami and earthquake hazards. To facilitate this increased understanding and to assist in product development, it is helpful to integrate the different datasets and then view the results in three-dimensional representations such as those displayed on the data integration and visualization sheet for the Offshore of Gaviota map area (sheet 4).

The maps and three-dimensional views on sheet 4 were created using a series of geographic information systems (GIS) and visualization techniques. Using GIS, the bathymetric and topographic data (sheet 1) were converted to ASCIIRASTER format files, and the acoustic-backscatter data (sheet 3) were converted to geoTIFF images. The bathymetric and topographic data were imported in the Fledermaus ${ }^{\circledR}$ software (QPS). The bathymetry was color-coded to closely match the colored shadedrelief bathymetry on sheet 1 in which reds and oranges represent shallower depths and blueish greens (and purples, in submarine canyons) represent deeper depths. Onshore topographic data were shown in gray shades. Acoustic-backscatter geoTIFF images also were draped over the bathymetry data (fig. 6). The colored bathymetry, topography, and draped backscatter were then tilted and panned to create the perspective views such as those shown in figures $1,2,4,5$, and 6 on sheet 4 . These views highlight the seafloor morphology in the Offshore of Gaviota map area, which includes asphalt mounds, rock outcrops, gullies, sediment mass-flow deposits, and linear striations interpreted as trawling scars.

Video-mosaic images created from digital seafloor video (for example, fig. 3 on sheet 4) can display the geologic complexity (rock, sand, and mud; see sheet 9) and biologic complexity (see Golden and Cochrane, 2013) of the seafloor. Whereas photographs capture high-quality snapshots of smaller areas of the seafloor, video mosaics capture larger areas and can show transition zones between seafloor environments. Digital seafloor video is collected from a camera sled towed approximately 1 to 2 meters above the seafloor, at speeds of less than 1 nautical mile/hour. Using standard video-editing software, as well as software developed at the Center for Coastal and Ocean Mapping, University of New Hampshire, the digital video is converted to AVI format, cut into 2-minute sections, and desampled to every second or third frame. The frames are merged together using pattern-recognition algorithms from one frame to the next and converted to a TIFF image. The images are then rectified to the bathymetry data using ship navigation recorded with the video and layback estimates of the towed camera sled.

Block diagrams that combine the bathymetry with seismic-reflection-profile data help integrate surface and subsurface observations, especially stratigraphic and structural relations (for example, fig. 1 on sheet 4). These block diagrams were created by converting digital seismic-reflection-profile data (Johnson and others, 2016) into TIFF images, while taking note of the starting and ending coordinates and maximum and minimum depths. The images were then imported into the Fledermaus ${ }^{\circledR}$ software as vertical images and merged with the bathymetry imagery. 


\title{
Chapter 4. Seafloor-Character Map of the Offshore of Gaviota Map Area (Sheet 5)
}

\author{
By Guy R. Cochrane and Stephen R. Hartwell
}

The California State Marine Life Protection Act (MLPA) calls for protecting representative types of habitat in different depth zones and environmental conditions. A science team, assembled under the auspices of the California Department of Fish and Wildlife (CDFW), has identified seven substratedefined seafloor habitats in California's State Waters that can be classified using sonar data and seafloor video and photography. These habitats include rocky banks, intertidal zones, sandy or soft ocean bottoms, underwater pinnacles, kelp forests, submarine canyons, and seagrass beds. The following five depth zones, which determine changes in species composition, have been identified: Depth Zone 1, intertidal; Depth Zone 2, intertidal to $30 \mathrm{~m}$; Depth Zone 3, 30 to $100 \mathrm{~m}$; Depth Zone 4, 100 to $200 \mathrm{~m}$; and Depth Zone 5, deeper than $200 \mathrm{~m}$ (California Department of Fish and Wildlife, 2008). The CDFW habitats, with the exception of depth zones, can be considered a subset of a broader classification scheme of Greene and others (1999) that has been used by the U.S. Geological Survey (USGS) (Cochrane and others, 2003, 2005). These seafloor-character maps are generalized polygon shapefiles that have attributes derived from Greene and others (2007).

A 2007 Coastal Map Development Workshop, hosted by the USGS in Menlo Park, California, identified the need for more detailed (relative to Greene and others' [1999] attributes) raster products that preserve some of the transitional character of the seafloor when substrates are mixed and (or) they change gradationally. The seafloor-character map, which delineates a subset of the CDFW habitats, is a GIS-derived raster product that can be produced in a consistent manner from data of variable quality covering large geographic regions.

The following five substrate classes are identified in the Offshore of Gaviota map area:

- Class I: Fine- to medium-grained smooth sediment

- Class II: Mixed smooth sediment and rock

- Class III: Rock and boulder, rugose

- Class IV: Medium- to coarse-grained sediment (in scour depressions)

- Class V: Anthropogenic material (rugged)

The seafloor-character map of the Offshore of Gaviota map area (sheet 5) was produced using video-supervised maximum-likelihood classification of the bathymetry and intensity of return from sonar systems, following the method described by Cochrane (2008). The two variants used in this classification were backscatter intensity and derivative rugosity. The rugosity calculation was performed using the Terrain Ruggedness (VRM) tool within the Benthic Terrain Modeler toolset v. 3.0 (Wright and others, 2012; available at http://esriurl.com/5754).

Classes I, II, and III values were delineated using multivariate analysis. Class IV (medium- to coarse-grained sediment, in scour depressions) values were determined on the basis of their visual characteristics, using both shaded-relief bathymetry and backscatter (slight depression in the seafloor, very high backscatter return). Class $\mathrm{V}$ (rugged anthropogenic material) values were determined on the basis of their visual characteristics and the known location of man-made features. The resulting map (gridded at $2 \mathrm{~m}$ ) was cleaned by hand to remove data-collection artifacts (for example, the trackline nadir).

On the seafloor-character map (sheet 5), the five substrate classes have been colored to indicate the California MLPA depth zones and the Coastal and Marine Ecological Classification Standard (CMECS) slope zones (Madden and others, 2008) in which they belong. The California MLPA depth 
zones are Depth Zone 1 (intertidal), Depth Zone 2 (intertidal to $30 \mathrm{~m}$ ), Depth Zone 3 (30 to $100 \mathrm{~m}$ ), Depth Zone 4 (100 to $200 \mathrm{~m}$ ), and Depth Zone 5 (greater than $200 \mathrm{~m}$ ); in the Offshore of Gaviota map area, only Depth Zones 2, 3, and 4 are present. The slope classes that represent the CMECS slope zones are Slope Class $1=$ flat $\left(0^{\circ}\right.$ to $\left.5^{\circ}\right)$, Slope Class $2=\operatorname{sloping}\left(5^{\circ}\right.$ to $\left.30^{\circ}\right)$, Slope Class $3=$ steeply sloping $\left(30^{\circ}\right.$ to $\left.60^{\circ}\right)$, Slope Class $4=$ vertical $\left(60^{\circ}\right.$ to $\left.90^{\circ}\right)$, and Slope Class $5=$ overhang (greater than $\left.90^{\circ}\right)$; in the Offshore of Gaviota map area, only Slope Classes 1, 2, and 3 are present. The final classified seafloor-character raster map image has been draped over the shaded-relief bathymetry for the area (sheets 1 and 2) to produce the image shown on the seafloor-character map on sheet 5 .

The seafloor-character classification also is summarized on sheet 5 in table 1. Fine- to mediumgrained smooth sediment (sand and mud) makes up 78.8 percent $\left(75.1 \mathrm{~km}^{2}\right)$ of the map area: 21.6 percent $\left(20.6 \mathrm{~km}^{2}\right)$ is in Depth Zone 2, 46.7 percent $\left(44.5 \mathrm{~km}^{2}\right)$ is in Depth Zone 3, and 10.5 percent $\left(10.0 \mathrm{~km}^{2}\right)$ is in Depth Zone 4. Mixed smooth sediment (sand and gravel) and rock (that is, sediment typically forming a veneer over bedrock, or rock outcrops having little to no relief) make up 16.2 percent $\left(15.4 \mathrm{~km}^{2}\right)$ of the map area: 6.1 percent $\left(5.9 \mathrm{~km}^{2}\right)$ is in Depth Zone 2, 8.0 percent $\left(7.7 \mathrm{~km}^{2}\right)$ is in Depth Zone 3, and 2.0 percent $\left(1.9 \mathrm{~km}^{2}\right)$ is in Depth Zone 4. Rock and boulder, rugose (rock outcrops, boulder fields, and asphalt mounds having high surficial complexity) makes up 4.9 percent $\left(4.7 \mathrm{~km}^{2}\right) \mathrm{of}$ the map area: 2.0 percent $\left(1.9 \mathrm{~km}^{2}\right)$ is in Depth Zone $2,1.7$ percent $\left(1.7 \mathrm{~km}^{2}\right)$ is in Depth Zone 3, and 1.3 percent $\left(1.2 \mathrm{~km}^{2}\right)$ is in Depth Zone 4. Medium- to coarse-grained sediment (in scour depressions consisting of material that is coarser than the surrounding seafloor), which makes up less than 0.1 percent $\left(<0.1 \mathrm{~km}^{2}\right)$ of the map area, is only present in Depth Zone 3. Rugged anthropogenic material makes up less than 0.1 percent $\left(<0.1 \mathrm{~km}^{2}\right)$ of the map area and is only present in Depth Zone 2 .

A small number of video observations and sediment samples were used to supervise the numerical classification of the seafloor. All video observations (see Golden and Cochrane, 2013) are used for accuracy assessment of the seafloor-character map after classification. To compare observations to classified pixels, each observation point is assigned a class (I, II, or III) according to the visually derived, major or minor geologic component (for example, sand or rock) and the abiotic complexity (vertical variability) of the substrate recorded during ground-truth surveys (table 4-1; see also, Golden and Cochrane, 2013). Class IV values were assigned on the basis of the observation of one or more of a group of features that includes both larger scale bedforms (for example, sand waves), as well as sediment-filled scour depressions that resemble the "rippled scour depressions" of Cacchione and others (1984), Hallenbeck and others (2012), and Davis and others (2013) and also the "sorted bedforms" of Murray and Thieler (2004), Goff and others (2005), and Trembanis and Hume (2011). On the geologic map (see sheet 9 of this report), they are referred to as "marine shelf scour depressions." Class V values are determined from the visual characteristics and known locations of man-made features.

Next, circular buffer areas were created around individual observation points using a 10-m radius to account for layback and positional inaccuracies inherent to the towed-camera system. The radius length is an average of the distances between the positions of sharp interfaces seen on both the video (the position of the ship at the time of observation) and sonar data, plus the distance covered during a 10 -second observation period at an average speed of 1 nautical mile/hour. Each buffer, which covers more than $300 \mathrm{~m}^{2}$, contains approximately 77 pixels. The classified (I, II, III) buffer is used as a mask to extract pixels from the seafloor-character map. These pixels are then compared to the class of the buffer. For example, if the shipboard-video observation is Class II (mixed smooth sediment and rock), but 12 of the 77 pixels within the buffer area are characterized as Class I (fine- to medium-grained smooth sediment), and 15 (of the 77) are characterized as Class III (rock and boulder, rugose), then the comparison would be "Class I, 12; Class II, 50; Class III, 15" (fig. 4-1). If the video observation of substrate is Class II, then the classification is accurate because the majority of seafloor pixels in the buffer are Class II. The accuracy values in table 4-2 represent the final of several classification iterations aimed at achieving the best accuracy, given the variable quality of sonar data (see discussion 
in Cochrane, 2008) and the limited ground-truth information available when compared to the continuous coverage provided by swath sonar. Presence/absence values in table 4-2 reflect the percentages of observations where the sediment classification of at least one pixel within the buffer zone agreed with the observed sediment type at a certain location.

The classification accuracies are shown in table 4-2. The weaker agreements in Class II (53.7 percent accurate) and Class III (42.9 percent accurate) likely are due to the relatively narrow and intermittent nature of transition zones from sediment to rock, as well as the size of the buffer. The buffer size was increased to $50 \mathrm{~m}$ for one deep video transect during which it was possible to measure the layback because just one rock outcrop was visible in both the multibeam data and the video. Percentages for presence/absence within a buffer also were calculated as a better measure of the accuracy of the classification for patchy rock habitat. The presence/absence accuracy was found to be significant for all classes that have video observations within the coverage of the seafloor-character map (80.7 percent for Class I, 77.8 percent for Class II, and 85.7 percent for Class III). No video observations or sediment samples were retrieved of Class IV (scour depressions) and Class V (rugged anthropogenic material); therefore, no accuracy assessments were performed for those classes.
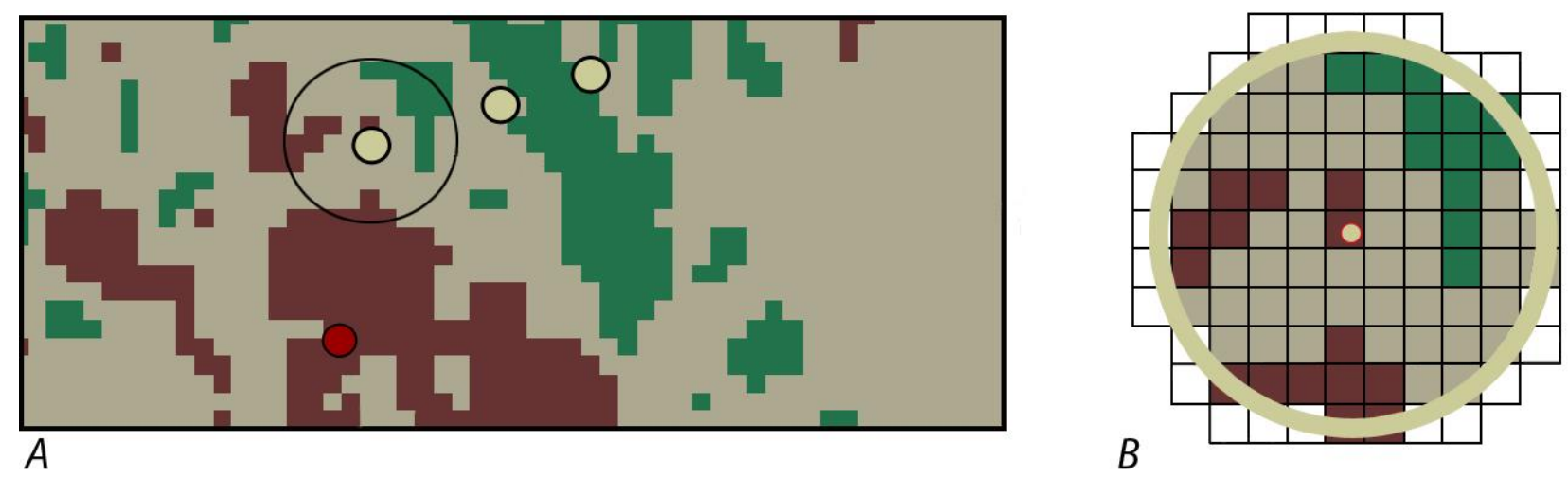

Figure 4-1. Detailed view of ground-truth data, showing accuracy-assessment methodology. $A$, Dots illustrate ground-truth observation points, each of which represents 10-second window of substrate observation plotted over seafloor-character grid; circle around dot illustrates area of buffer depicted in $B$. $B$, Pixels of seafloorcharacter data within 10-m-radius buffer centered on one individual ground-truth video observation. 
Table 4-1. Conversion table showing how video observations of primary substrate (more than 50 percent seafloor coverage), secondary substrate (more than 20 percent seafloor coverage), and abiotic seafloor complexity (in first three columns) are grouped into seafloor-character-map Classes I, II, and III for use in supervised classification and accuracy assessment in Offshore of Gaviota map area.

[In areas of low visibility where primary and secondary substrate could not be identified with confidence, recorded observations of substrate (in fourth column) were used to assess accuracy]

\begin{tabular}{|c|c|c|c|}
\hline Primary-substrate component & Secondary-substrate component & Abiotic seafloor complexity & Low-visibility observations \\
\hline \multicolumn{4}{|c|}{ Class I } \\
\hline mud & mud & low & \\
\hline mud & sand & low & \\
\hline sand & mud & low & \\
\hline sand & sand & moderate & \\
\hline & & & sediment \\
\hline & & & ripples \\
\hline \multicolumn{4}{|c|}{ Class II } \\
\hline cobbles & mud & low & \\
\hline cobbles & rock & low & \\
\hline cobbles & rock & moderate & \\
\hline cobbles & sand & moderate & \\
\hline gravel & mud & low & \\
\hline gravel & rock & low & \\
\hline mud & cobbles & low & \\
\hline mud & gravel & low & \\
\hline mud & rock & low & \\
\hline mud & rock & moderate & \\
\hline sand & cobbles & moderate & \\
\hline sand & gravel & low & \\
\hline sand & rock & low & \\
\hline sand & rock & moderate & \\
\hline \multicolumn{4}{|c|}{ Class III } \\
\hline boulders & boulders & high & \\
\hline boulders & cobbles & high & \\
\hline boulders & rock & moderate & \\
\hline boulders & rock & high & \\
\hline boulders & sand & high & \\
\hline boulders & sand & moderate & \\
\hline mud & rock & high & \\
\hline
\end{tabular}


Table 4-1. Conversion table showing how video observations of primary substrate (more than 50 percent seafloor coverage), secondary substrate (more than 20 percent seafloor coverage), and abiotic seafloor complexity (in first three columns) are grouped into seafloor-character-map Classes I, II, and III for use in supervised classification and accuracy assessment in Offshore of Gaviota map area.-Continued

\begin{tabular}{|l|l|l|l|}
\hline \multicolumn{5}{|c|}{ Primary-substrate component } & \multicolumn{1}{|c|}{ Secondary-substrate component } & \multicolumn{1}{c|}{ Abiotic seafloor complexity } & \multicolumn{1}{l|}{ Low-visibility observations } \\
\hline \multicolumn{5}{|c|}{ ClI-Continued } \\
\hline rock & boulders & high & \\
\hline rock & boulders & moderate & \\
\hline rock & cobbles & moderate & \\
\hline rock & mud & moderate & \\
\hline rock & rock & high & \\
\hline rock & rock & moderate & \\
\hline rock & sand & high & \\
\hline rock & sand & moderate & \\
\hline sand & rock & high & \\
\hline
\end{tabular}

Table 4-2. Accuracy-assessment statistics for seafloor-character-map classifications in Offshore of Gaviota map area.

[Accuracy assessments are based on video observations (N/A, no accuracy assessment was conducted)]

\begin{tabular}{|l|c|c|c|}
\hline \multicolumn{1}{|c|}{ Class } & Number of observations & \% majority & \% presence/absence \\
\hline I-Fine- to medium-grained smooth sediment & 191 & 72.4 & 80.7 \\
\hline II-Mixed smooth sediment and rock & 50 & 53.7 & 77.8 \\
\hline III-Rock and boulder, rugose & 11 & 42.9 & 85.7 \\
\hline IV-Medium- to coarse-grained sediment (in scour depressions) & 0 & N/A & N/A \\
\hline V-Rugged anthropogenic material & 0 & N/A & N/A \\
\hline
\end{tabular}




\title{
Chapter 5. Marine Benthic Habitats of the Offshore of Gaviota Map Area (Sheet 6)
}

\author{
By Guy R. Cochrane and Stephen R. Hartwell
}

The map on sheet 6 shows physical marine benthic habitats in the Offshore of Gaviota map area. Marine benthic habitats represent a particular type of substrate and geomorphology that may provide a habitat for a specific species or assemblage of organisms. Marine benthic habitats are classified using the Coastal and Marine Ecological Classification Standard (CMECS), developed by representatives from a consortium of Federal agencies. CMECS is the Federal standard for marine habitat characterization (available at https://www.fgdc.gov/standards/projects/FGDC-standards-projects/cmecs-folder/ CMECS_Version_06-2012_FINAL.pdf). The standard provides an ecologically relevant structure for biologic-, geologic-, chemical-, and physical-habitat attributes.

The map illustrates the geoform and substrate components of the CMECS standard and their distribution in the Offshore of Gaviota map area. Geoform components describe the major geomorphic and structural characteristics of the coast and seafloor (that is, the tectonic and physiographic settings and the geological, biogenic, and anthropogenic features). The map was derived from the geologic and geomorphic map of the seafloor (see sheet 9) by translation of the map-unit descriptions into the best-fit values of the CMECS classes. A geoform is found in the CMECS description when the geologic mapunit description includes a geomorphologic element. Geologic map units that lack grain size information, such as anthropogenic features, will correspondingly lack a CMECS substrate classification. The map also includes a temporal attribute for each unit that indicates time period of persistence, as well as an induration attribute that allows resymbolization of the data-catalog shapefile into a simple map of hard-mixed-soft attributes essential for fish-habitat assessment.

CMECS codes are provided in the data-catalog shapefile and in table 5-1 (the CMECS coding system is described at https://coast.noaa.gov/digitalcoast/sites/default/files/files/publications/21072015/ CMECS_Coding_System_Approach_20140619.pdf). Note that the CMECS codes are designed to facilitate database searching and sorting but are not used for map symbolization on the benthic habitat map (sheet 6); instead, polygons are labeled with a letter that identifies the CMECS physiographic setting (S, continental shelf; L, continental slope) and a number for each map unit within that setting (table 5-1).

\section{Map Area Habitats}

The Offshore of Gaviota map area includes the continental shelf and small parts of the upper slope in the western Santa Barbara Channel. Delineated on the map are 16 marine benthic habitat types: 13 types are located on the continental shelf, and 3 are located on the slope (table 5-1; see also, table 1 on sheet 6). The habitats include soft, unconsolidated sediment (9 habitat types) such as fine sand and mud and also just sand, as well as dynamic features such as mobile sand sheets, sediment waves, and rippled sediment depressions; mixed substrate ( 2 habitat types) such as intermittent sands that overlie hard consolidated bedrock; and hard substrate ( 3 habitat types) such as bedrock. In addition, two habitats that contain anthropogenic features (trawl marks and a pipeline) are mapped in the map area.

Of the total of $101.8 \mathrm{~km}^{2}$ mapped in the Offshore of Gaviota map area, $86.2 \mathrm{~km}^{2}$ (84.7 percent) is mapped in the continental shelf setting, and $15.6 \mathrm{~km}^{2}$ (15.3 percent) is mapped in the slope setting. In the continental shelf setting, "soft-induration" unconsolidated sediment is the dominant habitat type, covering $62.1 \mathrm{~km}^{2}$ (72.0 percent); "mixed-induration" substrate covers $10.4 \mathrm{~km}^{2}$ (12.0 percent); and "hard-induration" rock and boulders cover $12.6 \mathrm{~km}^{2}$ (14.6 percent) (terminology from Greene and others, 2007). On the continental shelf, $1.1 \mathrm{~km}^{2}$ (1.1 percent) of the seafloor is covered by trawling 
marks. In the slope setting, unconsolidated sediment is the dominant habitat type, covering $15.5 \mathrm{~km}^{2}$ (99.4 percent); and rock and boulders cover $0.1 \mathrm{~km}^{2}$ ( 0.6 percent).

Table 5-1. Marine benthic habitats from Coastal and Marine Ecological Classification Standard mapped in Offshore of Gaviota map area, showing description and total area, in square meters, of each.

\begin{tabular}{|c|c|c|c|}
\hline $\begin{array}{l}\text { Map-unit } \\
\text { label }\end{array}$ & CMECS code & Description & $\begin{array}{l}\text { Area, in square } \\
\text { meters }\end{array}$ \\
\hline S1 & Gt8p6g1.49S1.2.2.2.3SI3P9 & $\begin{array}{l}\text { Transform Continental Margin. Continental/Island Shelf. Ripples. } \\
\text { Medium Sand. Soft Substrate Induration. Decades Persistence }\end{array}$ & $27,854,140$ \\
\hline S2 & Gt8p6g1.49g1.64S1.2.2.2S1.1.1SI2P8 & $\begin{array}{l}\text { Transform Continental Margin. Continental/Island Shelf. Ripples. Rock } \\
\text { Outcrop. Sand. Bedrock. Mixed Substrate Induration. Years Persistence }\end{array}$ & $10,364,978$ \\
\hline S3 & Gt8p6g1.50S1.1.1SI1P10 & $\begin{array}{l}\text { Transform Continental Margin. Continental/Island Shelf. Rock } \\
\text { Outcrop. Bedrock. Hard Substrate Induration. Centuries Persistence }\end{array}$ & $12,434,811$ \\
\hline S4 & Gt8p6g1.46S1.2.2SI3P9 & $\begin{array}{l}\text { Transform Continental Margin. Continental/Island Shelf. Pockmark } \\
\text { Field. Fine Unconsolidated Substrate. Soft Substrate Induration. } \\
\text { Decades Persistence }\end{array}$ & $1,068,996$ \\
\hline S5 & Gt8p6g1S1.2.1.2.1SI2p9 & $\begin{array}{l}\text { Transform Continental Margin. Continental/Island Shelf. Sandy Gravel. } \\
\text { Soft Substrate Induration. Decades Persistence }\end{array}$ & 291,658 \\
\hline S6 & Gt8p6g1S1.2.2.4.2SI3P9 & $\begin{array}{l}\text { Transform Continental Margin. Continental/Island Shelf. Sandy Silt- } \\
\text { Clay. Soft Substrate Induration. Decades Persistence }\end{array}$ & $12,574,410$ \\
\hline S7 & Gt8p6g1.14.1S1.2.1.3.1SI3P9 & $\begin{array}{l}\text { Transform Continental Margin. Continental/Island Shelf. Scour } \\
\text { Depression. Gravelly Sand. Soft Substrate Induration. Decades } \\
\text { Persistence }\end{array}$ & 7,111 \\
\hline S9 & Gt8p6g1.64S1.2.1.2.1SI2p9 & $\begin{array}{l}\text { Transform Continental Margin. Continental/Island Shelf. Submarine } \\
\text { Slide Deposit. Sandy Gravel. Soft Substrate Induration. Decades } \\
\text { Persistence }\end{array}$ & 349,274 \\
\hline S10 & Gt8p6g1.39.1S1.1SI1P10 & $\begin{array}{l}\text { Transform Continental Margin. Continental/Island Shelf. Tar Mound. } \\
\text { Rock Substrate. Hard Substrate Induration. Centuries Persistence }\end{array}$ & 146,355 \\
\hline S11 & Gt8p6g3.5.2P9 & $\begin{array}{l}\text { Transform Continental Margin. Continental/Island Shelf. Trawling } \\
\text { Scar. Decades Persistence }\end{array}$ & $1,116,801$ \\
\hline S13 & Gt8p6g1.1S1.2.1.3.1SI3P9 & $\begin{array}{l}\text { Transform Continental Margin. Continental/Island Shelf. Apron. } \\
\text { Gravelly Sand. Soft Substrate Induration. Decades Persistence }\end{array}$ & $13,840,013$ \\
\hline S14 & Gt8p6g3.8P9 & $\begin{array}{l}\text { Transform Continental Margin. Continental/Island Shelf. Pipeline Area. } \\
\text { Decades Persistence }\end{array}$ & 41,005 \\
\hline S15 & Gt8p6g1.3S1.2.1.2.1SI2P9 & $\begin{array}{l}\text { Transform Continental Margin. Continental/Island Shelf. Bar. Sandy } \\
\text { Gravel. Mixed Substrate Induration. Decades Persistence }\end{array}$ & $6,117,475$ \\
\hline $\bar{L} 1$ & Gt8p8g1.52S1.2.2.3.1SI3P9 & $\begin{array}{l}\text { Transform Continental Margin. Continental/Island Slope. Runnel/Rill. } \\
\text { Silty Sand. Soft Substrate Induration. Decades Persistence }\end{array}$ & $3,239,731$ \\
\hline L2 & Gt8p8g1S1.2.2.4.2SI3P8 & $\begin{array}{l}\text { Transform Continental Margin. Continental/Island Slope. Sandy Silt- } \\
\text { Clay. Soft Substrate Induration. Years Persistence }\end{array}$ & $12,246,730$ \\
\hline L3 & Gt8p8g1.50S1.1.1SI1P10 & $\begin{array}{l}\text { Transform Continental Margin. Continental/Island Slope. Rock } \\
\text { Outcrop. Bedrock. Hard Substrate Induration. Centuries Persistence }\end{array}$ & 99,409 \\
\hline
\end{tabular}




\title{
Chapter 6. Subsurface Geology and Structure of the Offshore of Gaviota Map Area and the Santa Barbara Channel Region (Sheets 7 and 8)
}

\author{
By Samuel Y. Johnson and Stephen R. Hartwell
}

The seismic-reflection profiles presented on sheet 7 provide a third dimension-depth beneath the seafloor-to complement the surficial seafloor-mapping data already presented (sheets 1 through 6) for the Offshore of Gaviota map area. These data, which are collected at several resolutions, extend to varying depths in the subsurface, depending on the purpose and mode of data acquisition. The seismicreflection profiles (sheet 7) provide information on sediment character, distribution, and thickness; the profiles also provide information on potential geologic hazards, which include (1) active faults, such as the south strand of the Santa Ynez Fault, (2) areas that are prone to strong ground motion, and (3) areas that have potential for slope failure, such as on the shelf break and the seaward margin of the Gaviota sediment bar. The information on faults provides essential input to national and state earthquake-hazard maps and assessments (see, for example, Petersen and others, 2014).

The maps on sheet 8 show the following interpretations, which are based on the seismicreflection profiles on sheet 7: the thickness of the composite uppermost Pleistocene and Holocene sediment unit; the depth to base of this uppermost unit; and both the local and regional distribution of faults and earthquake epicenters (includes new data from this report, as well as from Jennings and Bryant, 2010; U.S. Geological Survey and California Geological Survey, 2016; and U.S. Geological Survey, 2016).

\section{Data Acquisition}

Most profiles displayed on sheet 7 (figs. 1, 2, 3, 4, 5, 7, 8, 9, 10) were collected in 2014 on U.S. Geological Survey (USGS) cruise S-01-13-SC, using the SIG 2Mille minisparker system. This system used a 500-J high-voltage electrical discharge fired 1 to 2 times per second, which, at normal survey speeds of 4 to 4.5 nautical miles per hour, gives a data trace every 1 to $2 \mathrm{~m}$ of lateral distance covered. The data were digitally recorded in standard SEG-Y 32-bit floating-point format, using Triton Subbottom Logger (SBL) software that merges seismic-reflection data with differential GPS-navigation data. After the survey, a short-window $(20 \mathrm{~ms})$ automatic gain control algorithm was applied to the data, along with a 160 - to $1,200-\mathrm{Hz}$ bandpass filter and a heave correction that uses an automatic seafloordetection window (averaged over $30 \mathrm{~m}$ of lateral distance covered). These data can resolve geologic features a few meters thick (and, hence, are considered "high-resolution"), down to subbottom depths of as much as $400 \mathrm{~m}$.

Figure 6 on sheet 7 shows a migrated, deep-penetration, multichannel seismic-reflection profile collected in 1984 by WesternGeco on cruise W-37-84-SC. This profile and other similar data were collected in many areas offshore of California in the 1970s and 1980s when these areas were considered a frontier for oil and gas exploration. Much of these data have been publicly released and are now archived at the U.S. Geological Survey National Archive of Marine Seismic Surveys (Triezenberg and others, 2016). These data were acquired using a large-volume air-gun source that has a frequency range of 3 to $40 \mathrm{~Hz}$ and recorded with a multichannel hydrophone streamer about $2 \mathrm{~km}$ long. Shot spacing was about $30 \mathrm{~m}$. These data can resolve geologic features that are 20 to $30 \mathrm{~m}$ thick, down to subbottom depths of as much as $4 \mathrm{~km}$. 


\section{Seismic-Reflection Imaging of the Continental Shelf}

Sheet 7 shows seismic-reflection profiles in the offshore part of the Offshore of Gaviota map area, providing an image of the subsurface geology. Shelf width in the map area ranges from about 4.5 to $6 \mathrm{~km}$. Shelf slopes in the map area are highly variable because of the presence of the large Gaviota sediment bar (see, for example, figs. 4, 5, 7, 8, 10 on sheet 7), which extends obliquely southwestward across the shelf for about $11 \mathrm{~km}$ (sheet 9). In the east half of the map area, the shelf break is at a depth of about 87 to $91 \mathrm{~m}$ and trends about $276^{\circ}$ azimuth. Farther west, the shelf break is notably embayed, bends to a trend of about $236^{\circ}$ azimuth, and is as shallow as 62 to $73 \mathrm{~m}$ in an area of significant slope failure (discussed below).

The shelf is underlain by Neogene sedimentary rocks and uppermost Pleistocene to Holocene sediments (see sheet 9). Neogene units include the Miocene Monterey Formation and the upper Miocene and lower Pliocene Sisquoc Formation. On high-resolution seismic-reflection profiles, these strata commonly yield parallel to subparallel, continuous, variable-amplitude, high-frequency reflections (terminology from Mitchum and others, 1977); however, these strata commonly are commonly folded, in many places too steeply folded to be imaged on seismic-reflection profiles. Local zones that lack reflections probably also are the result of the presence of interstitial gas within the sediments. This effect has been referred to as "gas blanking," "acoustic turbidity," or "acoustic masking" (Hovland and Judd, 1988; Fader, 1997). The gas scatters or attenuates the acoustic energy, preventing penetration. Not surprisingly, this effect is especially prevalent near the Molino Anticline (see figs. 7, 8, 10 on sheet 7) and near the crests of other small anticlines.

Eustasy was an important control on latest Pleistocene to Holocene shelf deposition in the Offshore of Gaviota map area. Surficial and shallow sediments were deposited on the shelf in the last about 21,000 years during the sea-level rise that followed the last major lowstand and the Last Glacial Maximum (LGM) (Stanford and others, 2011). Global sea level was about 120 to $130 \mathrm{~m}$ lower during the LGM, at which time the shelf on the north flank of the Santa Barbara Channel was emergent. The post-LGM sea-level rise was rapid (about 9 to $11 \mathrm{~m}$ per thousand years) until about 7,000 years ago, when it slowed considerably to about $1 \mathrm{~m}$ per thousand years (Peltier and Fairbanks, 2006; Stanford and others, 2011). The sediments deposited on the shelf during the post-LGM sea-level rise (above a transgressive surface of erosion) are shaded blue in many of the high-resolution seismic-reflection profiles (figs. 1, 2, 3, 4, 5, 6, 7, 8, 10 on sheet 7), and their thicknesses are shown on sheet 8 .

On most profiles, the base of the post-LGM depositional unit is a flat to concave, angular unconformity characterized by an obvious change in reflectivity. The post-LGM sediment unit has its maximum thickness (36 m) in the Gaviota sediment bar (figs. 4, 5, 7, 8, 10 on sheet 7), which is as wide as $2 \mathrm{~km}$ and extends southwestward for about $9 \mathrm{~km}$ from the mouth of Cañada de la Gaviota to the shelf break. The bar, which faces southeast, has a relatively flat (about $1.4^{\circ}$ ) top that extends to water depths of $60 \mathrm{~m}$. The steep (as much as $5^{\circ}$ ) bar front, formed by advancing clinoforms (see figs. 4, 5 on sheet 7), is bounded seaward by an apron of coalescing slump deposits and mass-flow lobes (see figs. 7, 8 on sheet 7; see also, sheets 1, 2, 9). Post-LGM sediment thins markedly, and is locally absent, both southeast and northwest of the Gaviota sediment bar.

All but the westernmost one-sixth (about $2 \mathrm{~km}$ wide) of the map area includes the shelf break and upper slope. For the eastern two-fifths (about $7 \mathrm{~km}$ wide) of the map area, the shelf break is relatively sharp, and it locally contains a relatively thin (as much as $12 \mathrm{~m}$ ) mound of sediment that is interpreted as a lowstand shelf-break delta (see figs. 7, 8 on sheet 7). Seismic-reflection profiles that cross the smooth upper slope south of the shelf break reveal continuous, subparallel, offshore-dipping reflections (see figs. 7, 8, 10 on sheet 7), inferred to represent LGM-lowstand and older Quaternary deposits. Although the upper slope in this area is locally as steep as $6^{\circ}$, the seismic-reflection data lack the chaotic to massive reflections that are interpreted as buried landslide deposits in the Goleta landslide 
complex to the east (Fisher and others, 2005; Greene and others, 2006; Lee and others, 2009) and the Conception fan to the west.

Farther west, the shelf break and the distal portion of the Gaviota sediment bar are incised by three large (150- to 300-m-wide) channels (see sheets 1,2,9) that have been referred to as "the Gaviota Canyons" (Fischer and Cherven, 1998) or as "Drake Canyon," "Sacate Canyon," and "Alegria Canyon" (Eichhubl and others, 2002). The upper slope below this part of the shelf break consists of a hummocky, incised debris apron, referred to as the Conception fan (Fischer and Cherven, 1998; Eichhubl and others, 2002). Seismic-reflection profiles that cross the hummocky upper slope reveal massive, reflection-free zones and chaotic reflections (see figs. 1,2, 4, 5 on sheet 7) that are interpreted as submarine-landslide deposits, in marked contrast to the smooth slope and continuous reflections that characterize the upper slope to the east (see figs. 7, 8, 10 on sheet 7).

\section{Geologic Structure and Recent Deformation}

High-resolution seismic-reflection profiles in the Offshore of Gaviota map area (sheet 7) primarily show Neogene strata that, on a larger scale, are folded within a large, east-west-striking homocline that extends from the south flank of the Santa Ynez Mountains (fig. 1-2) into the offshore. The homocline formed above the blind Pitas Point-North Channel Fault system (fig. 1-3), as indicated on nearby regional cross sections (Tennyson and Kropp, 1998; Redin and others, 2005) and on industry seismic-reflection profiles (see fig. 6 on sheet 7; see also, Sorlien and Nicholson, 2015). The tip of the fault system is inferred to be buried to a depth of about $2 \mathrm{~km}$ below sea level (about $1.5 \mathrm{sec} \mathrm{TWT}^{6}$ ) about $10 \mathrm{~km}$ offshore, beneath the slope on the north flank of the Santa Barbara Basin.

The southwest-striking south strand of the Santa Ynez Fault (see figs. 3, 4, 5 on sheet 7; see also, sheet 9) obliquely cuts the shelf in the western part of the map area. As mapped onshore by Dibblee (1950, 1988a,b), this fault is unique among Santa Barbara fold-belt structures in that it obliquely crosses the Santa Ynez Mountains and the dominant east-west-trending structural grain. In the offshore, the fault was difficult to map, despite our dense coverage of seismic-reflection data (see trackline map on sheet 7), because (1) the pre-LGM section on the shelf includes massive, reflection-free zones that probably are caused by interstitial gas or steeply dipping strata, and (2) the adjacent slope is mainly underlain by the massive to chaotic seismic facies of the Conception fan (see figs. 1, 2, 4, 5 on sheet 7).

The hanging wall of the Pitas Point-North Channel Fault system (fig. 1-3) is inferred to include several blind splays that are structurally above the main fault, on the basis of the irregular pattern of shallow folds in the map area. Closely spaced seismic-reflection profiles reveal many shallow folds that have variable geometries, lengths, amplitudes, degrees of continuity, and wavelengths (see sheets 7, 9). The most continuous folds are the 17-km-long Molino Anticline (host of the Molino gas field) and the 22-km-long Government Point Syncline, both of which are truncated to the west and east, respectively, by the south strand of the Santa Ynez Fault zone (see sheets 8,9).

The regional pattern of faults and earthquakes occurring between 1932 and June 14, 2016, that have inferred or measured magnitudes greater than 2.0 are shown on Map $\mathrm{C}$ on sheet 8 . Although locations have been provided by the CalTech network since 1932, significantly greater precision began in 1969 with installation of a USGS seismographic network (see, for example, Lee and Vedder, 1973; Sylvester, 2001; U.S. Geological Survey, 2016). Epicentral data indicate that seismicity in the western and central Santa Barbara Channel is characterized by earthquake swarms, relatively frequent minor earthquakes, and infrequent major earthquakes.

Three significant earthquakes affected the Santa Barbara Channel area prior to 1932 (the year of the earliest earthquake in the U.S. Geological Survey [2016] catalog): in 1812, 1857 (the Fort Tejon earthquake on the San Andreas Fault), and 1925 (Stover and Coffman, 1993). Sylvester and others

\footnotetext{
${ }^{6}$ Two-way travel time
} 
(1970) reported a location in the northern Santa Barbara Channel for the 1925 event (M6.3), as well as for a 1941 earthquake ( M5.5, 7/1/1941) about $7 \mathrm{~km}$ offshore and $15 \mathrm{~km}$ southeast of Santa Barbara, the largest one shown on Map C (sheet 8). In addition, Sylvester and others (1970) documented a swarm of 62 earthquakes (M2.5-M5.2) that occurred between 6/26/1968 and 8/3/1968, which also were located 10 to $15 \mathrm{~km}$ south (offshore) of Santa Barbara. The largest recorded event in the Offshore of Gaviota map area ( M3.1) occurred on 11/4/1987, about $7 \mathrm{~km}$ south of Gaviota (U.S. Geological Survey, 2016).

\section{Thickness and Depth to Base of Uppermost Pleistocene and Holocene Deposits}

Maps on sheet 8 show the thickness and the depth to base (from sea level) of uppermost Pleistocene and Holocene (post-LGM) deposits both for the Offshore of Gaviota map area (Maps A, B) and, to establish regional context, for a larger area (about $130 \mathrm{~km}$ of coast) that extends from the vicinity of Hueneme Canyon northwest to Point Conception (Maps D, E). To make these maps, water bottom and depth to base of the uppermost Pleistocene and Holocene sediment layers were mapped from seismic-reflection profiles (see sheet 7). The difference between the two horizons was exported for every shot point as XY coordinates (UTM zone 10) and two-way travel time (TWT). The thickness of the uppermost Pleistocene and Holocene unit (Maps B, E) was determined by applying a sound velocity of $1,600 \mathrm{~m} / \mathrm{sec}$ to the TWT. The thickness points were interpolated to a preliminary continuous surface, overlaid with zero-thickness bedrock outcrops (see sheet 9), and contoured, following the methodology of Wong and others (2012). Data within Hueneme Canyon were excluded from the contouring because the seismic-reflection data are too sparse to adequately image the highly variable changes in sediment thickness that characterize the canyon.

Several factors required manual editing of the preliminary thickness maps to make the final product. The Red Mountain Fault Zone, Pitas Point Fault, and Oak Ridge Fault disrupt the sediment sequence in the region (Maps D, E on sheet 8). In addition, the thickness data points are dense along tracklines (about $1 \mathrm{~m}$ apart) and sparse between tracklines (1 to $2 \mathrm{~km}$ apart), resulting in contouring artifacts. To incorporate the effect of the faults, to remove irregularities from interpolation, and to reflect other geologic information and complexity, the resulting interpolated contours were modified. Contour modifications and regridding were repeated several times to produce the final regional sedimentthickness map. Data for the depth to base of the uppermost Pleistocene and Holocene unit (Maps A, D) were generated by adding the thickness data to water depths determined by multibeam bathymetry (see sheet 1).

In the Offshore of Gaviota map area, the thickness of the uppermost Pleistocene and Holocene sediments on the continental shelf ranges from 0 to $36 \mathrm{~m}$ (Map B on sheet 8). Mean sediment thickness on the shelf in the map area is $9.9 \mathrm{~m}$, and the total sediment volume on the shelf is $853 \times 10^{6} \mathrm{~m}^{3}$ (table 6-1). The thickest sediment in the map area (about $36 \mathrm{~m}$ ) is found within the Gaviota sediment bar. The primary sediment source, Cañada de la Gaviota, is the largest coastal watershed (about $52 \mathrm{~km}^{2}$; Warrick and Mertes, 2009) between the Ventura River and Point Conception. Sediment is notably thin or lacking on the shelf southeast and northwest of the Gaviota sediment bar, commonly forming only a thin veneer over bedrock outcrops.

Five different "domains" of sediment thickness, which are bounded either by faults or by Hueneme Canyon, are recognized on the regional maps (Maps D, E on sheet 8): (1) north of the south strand of the Red Mountain Fault Zone; (2) between the south strand of the Red Mountain Fault Zone and the Pitas Point Fault; (3) between the Pitas Point and Oak Ridge Faults; (4) between the Oak Ridge Fault and Hueneme Canyon; and (5) south of Hueneme Canyon. Table 6-1 shows the area of these five domains, along with estimates of their mean sediment thickness and total sediment volume. These data highlight the contrast among three general zones of sediment thickness: (1) the uplifted, sediment-poor Santa Barbara and Point Conception shelf (domain 1; mean sediment thickness of $4.2 \mathrm{~m}$ ); (2) a transitional zone (domain 2; mean sediment thickness of $18.0 \mathrm{~m}$ ); and (3) the subsiding, sediment-rich 
delta and shelf offshore of the Ventura and Santa Clara Rivers and Calleguas Creek (domains 3, 4, and 5; mean sediment thicknesses of 39.2, 38.9, and $28.3 \mathrm{~m}$, respectively).

Table 6-1. Area, sediment-thickness, and sediment-volume data for California's State Waters in Santa Barbara Channel region, between Point Conception and Hueneme Canyon areas (domains 1-5), as well as in the Offshore of Gaviota map area.

[Data from within Hueneme Canyon were not included in this analysis]

\begin{tabular}{|l|c|c|c|}
\hline \multicolumn{4}{|c|}{ Regional sediment-thickness domains in Santa Barbara Channel region } \\
\hline & Area (km²) & $\begin{array}{c}\text { Mean sediment } \\
\text { thickness (m) }\end{array}$ & Sediment volume (106 $\left.\mathbf{m}^{3}\right)$ \\
\hline $\begin{array}{l}\text { (1) Point Conception to south strand of Red Mountain Fault } \\
\text { Zone }\end{array}$ & 597.9 & 4.2 & 2,507 \\
\hline $\begin{array}{l}\text { (2) South strand of Red Mountain Fault Zone to Pitas Point } \\
\text { Fault }\end{array}$ & 67.1 & 18.0 & 1,205 \\
\hline $\begin{array}{l}\text { (3) Pitas Point Fault to Oak Ridge Fault } \\
\text { (4) Oak Ridge Fault to Hueneme Canyon }\end{array}$ & 78.6 & 39.2 & 2,688 \\
\hline (5) South of Hueneme Canyon & 53.9 & 38.9 & 2,933 \\
\hline & 85.8 & 28.3 & 1,527 \\
\hline Offshore of Gaviota map area & 75.4 & 853 \\
\hline
\end{tabular}




\title{
Chapter 7. Geologic and Geomorphic Map of the Offshore of Gaviota Map Area (Sheet 9)
}

\author{
By Samuel Y. Johnson and Stephen R. Hartwell
}

\section{Geologic and Geomorphic Summary}

Marine geology and geomorphology were mapped in the Offshore of Gaviota map area from the shoreline to the 3-nautical-mile limit of California's State Waters. The location of the shoreline, which is from the National Oceanic and Atmospheric Administration's (NOAA's) Shoreline Data Explorer, is based on their analysis of lidar imagery (National Geodetic Survey, 2016). Offshore geologic units were delineated on the basis of integrated analyses of adjacent onshore geology with multibeam bathymetry and backscatter imagery (sheets 1,2,3), seafloor-sediment and rock samples (Reid and others, 2006), digital camera and video imagery (Golden and Cochrane, 2013), and high-resolution seismic-reflection profiles (sheet 7). Bathymetric lidar and aerial photographs taken in multiple years were used to map the nearshore area (0 to $10 \mathrm{~m}$ water depth) and to link the offshore and onshore geology.

The onshore geology was compiled from Dibblee (1988a,b); unit ages, which are derived from these sources, reflect local stratigraphic relations. In addition, some Quaternary units were modified by C.W. Davenport on the basis of analysis of 2004 ifSAR and 2009 lidar imagery.

The offshore part of the map area largely consists of a narrow (4- to 5-km-wide), gently (about $1^{\circ}$ to $1.5^{\circ}$ ) offshore-dipping shelf underlain by Neogene bedrock, as well as Holocene sediments that are derived primarily from Cañada de la Gaviota and smaller coastal watersheds that drain the Santa Ynez Mountains (fig. 1-2). Holocene nearshore and shelf deposits are primarily sand (unit Qms). Coarser grained sediments (unit Qmsc) are found mainly along the Gaviota sediment bar, a prominent bathymetric feature that extends southwestward for about $9 \mathrm{~km}$ from the mouth of Cañada de la Gaviota to the shelf break. The Gaviota sediment bar, which faces southeast, is as wide as $2 \mathrm{~km}$ and has a relatively flat (about $1.4^{\circ}$ ) top that extends to water depths of $60 \mathrm{~m}$. The steep (as much as $5^{\circ}$ ) bar front, which formed by advancing clinoforms (see fig. 5 on sheet 7), is bounded by an apron of coalescing, hummocky debris-flow lobes (unit Qda). Coarser grained sediment also is present in the eastern part of a small scour depression (unit Qmsd), found along the west edge of the map area, at a water depth of about $35 \mathrm{~m}$. Sandy seafloor (unit aft) that is crossed by very low relief (about 10 to $20 \mathrm{~cm}$ high), widely spaced (about 5 to $15 \mathrm{~m}$ apart), northeast-trending ridges is found in two areas about $3.5 \mathrm{~km}$ south of the Gaviota shoreline, in water depths of about 40 to $55 \mathrm{~m}$; the morphology of these ridges, which cover about $1,116,802 \mathrm{~m}^{2}$ of seafloor, suggests that they were formed by fishing trawls.

Two subtle sediment lobes (unit Qmscl) are mapped near the east edge of the map area on the basis of their high backscatter and positive seafloor relief. These lobes, which occupy 257,490 and $92,932 \mathrm{~m}^{2}$, are found about 1,080 to 2,100 m offshore, in water depths of 35 to $55 \mathrm{~m}$. The lobes are located offshore of the mouths of steep coastal watersheds, and they have been interpreted as the deposits of debris flows or hyperpycnal flows, or a combination of these processes (Warrick and others, 2013; Steel and others, 2015). Preliminary ages (Steel and others, 2015) on similar features to the east indicate that they may have formed as early as 8,500 years ago when sea level was significantly lower (Steel and others, 2015).

Finer grained sediment - the very fine sand, silt, and clay of unit Qmsf-is mapped primarily in the eastern part of the map area, between depths of about $60 \mathrm{~m}$ and the shelf break. The boundary between units Qms and Qmsf is based on observations and extrapolation from sparse sediment sampling (for example, Reid and others, 2006) and camera ground-truth surveying (Golden and Cochrane, 2013). Thus, the boundary between units Qms and Qmsf should be considered transitional 
and approximate and is expected to shift as a result of seasonal- to annual- to decadal-scale cycles in wave climate, sediment supply, and sediment transport.

Fine-grained deposits similar to unit Qmsf also are found below the shelf break on the upper slope, at water depths greater than $90 \mathrm{~m}$, where they are mapped as a separate unit (unit Qmsl) on the basis of their location and geomorphology. Both the shelf break and the distal part of the Gaviota sediment bar are incised by narrow rills and three large (150- to 300-m-wide) channels (collectively mapped as unit Qmcr) that have been referred to either as "the Gaviota Canyons" (Fischer and Cherven, 1998) or as "Drake Canyon," "Sacate Canyon," and "Alegria Canyon" (Eichhubl and others, 2002).

East of the south strand of the Santa Ynez Fault, bedrock exposures along the shoreline and on the inner shelf consist of siliceous and calcareous mudstone and shale of the Miocene Monterey Formation (unit Tm). West of this fault strand, bedrock outcrops in the nearshore and on the shelf consist primarily of marine shale, claystone, and diatomite of the upper Miocene and lower Pliocene Sisquoc Formation (unit Tsq). Seafloor outcrops of units Tm and Tsq both commonly have a "ribbed" appearance, reflecting the differential erosion of variably resistant interbeds. Because of the lack of sampling and their relative lack of distinctive seafloor morphology, some seafloor bedrock outcrops on the outer shelf cannot be confidently assigned to either unit Tm or unit Tsq; these areas are mapped as the undivided Tertiary bedrock unit (Tbu).

Bedrock is, in some places, overlain by a thin (less than $1 \mathrm{~m}$ ?) veneer of sediment, recognized on the basis of high backscatter, flat relief, continuity with moderate- to high-relief bedrock outcrops, and (in some cases) high-resolution seismic-reflection data; these areas, which are mapped as composite units Qms/Tm, Qms/Tsq, Qms/Tbu, or Qmsf/Tbu, are interpreted as ephemeral sediment layers that may or may not be continuously present, whose presence or absence is a function of the recency and intensity of storm events, seasonal and (or) annual patterns of sediment movement, or longer term climate cycles.

The Santa Barbara Channel region is a mature hydrocarbon province that has a long history of petroleum exploration and production (Kunitomi and others, 1998). The Offshore of Gaviota map area includes the western part of the Molino offshore gas field, as well as the Gaviota and Caliente offshore gas fields and the Alegria and Cuarta offshore oil fields (Yerkes and others, 1969). Seafloor geomorphic features associated with petroleum seepage include fields of dense pockmarks (unit Qmp), asphalt mounds (unit Qas), carbonate mats, and mud volcanoes (see, for example, Keller and others, 2007). The pockmarks in the map area are predominantly grouped or, less commonly, solitary; are circular to elliptical; range in size from 50 to $150 \mathrm{~m}$ along their long axis; typically are 20 to $40 \mathrm{~cm}$ deep; and commonly have a central cone as much as $150 \mathrm{~cm}$ high. The largest field of pockmarks $\left(709,384 \mathrm{~m}^{2}\right)$ is along the trace of the south strand of the Santa Ynez Fault, along which fractured bedrock may provide a conduit for seepage. Asphalt mounds in the map area are found along and near the crest of the Molino Anticline where they generally are less than $4 \mathrm{~m}$ high and less than $40 \mathrm{~m}$ in diameter (Lorenson and others, 2014); Draut and others (2009) noted that such mounds likely consist of a mixture of tar and sediment. Lorenson and others (2014) calculated a composite volume of asphalt in the Gaviota area of $4.5 \times 10^{5} \mathrm{~m}^{3}$. Offshore pipelines, which are associated with offshore oil and gas development, are mapped as unit af. The relative proportions of all offshore map units are shown in table 7-1.

Neogene strata are deformed in a fold belt that, on a regional scale, is located within a large, east-west-striking, south-dipping homocline that extends from the south flank of the Santa Ynez Mountains into the offshore. Nearby regional cross sections (Redin and others, 2005) and industry seismic-reflection profiles (see fig. 6 on sheet 7; see also, Sorlien and Nicholson, 2015) showed that the homocline formed above the blind Pitas Point-North Channel Fault system, which in the offshore extends westward for more than $100 \mathrm{~km}$, from Pitas Point (10 km northwest of Ventura) to beyond Gaviota and Point Conception (fig. 1-3). South of Gaviota, the tip of the Pitas Point-North Channel 
Fault is inferred to be buried beneath the slope about $10 \mathrm{~km}$ offshore, to a depth of about 2 to $3 \mathrm{~km}$ below sea level.

The southwest-striking south strand of the Santa Ynez Fault, as mapped onshore by Dibblee (1988b), is unique among Santa Barbara fold-belt structures in that it obliquely crosses the Santa Ynez Mountains and the dominant east-west-trending structural grain. In the offshore, the fault was difficult to map, despite our dense coverage of seismic-reflection data (see sheet 7), because (1) the pre-LGM section on the shelf includes massive, reflection-free zones, probably caused by either interstitial gas or steeply dipping strata, and (2) the adjacent slope is mainly underlain by the massive to chaotic seismic facies of the Conception fan. The location of the fault on our map coincides with the northwestern margin of the Gaviota sediment bar on the midshelf to outer shelf (see fig. 1-2; see also, sheets 1, 2), suggesting that faulting may have been a control on bar development. In contrast to previously published offshore mapping of Fischer (1998), we map the Santa Ynez Fault as having a straighter strike (at about $224^{\circ}$ azimuth) and being located as much as $900 \mathrm{~m}$ farther northwest on the midshelf to outer shelf. Both Fischer (1998) and Eichhubl and others (2002) inferred that the SantaYnez Fault "captured" the heads of "Drake Canyon" and "Sacate Canyon" at the shelf break; indeed, the linearity of these canyon heads is striking, and it suggests left-lateral slip. Accordingly, our map shows a secondary, discontinuous strand of the fault that extends through these canyon heads; however, we cannot trace these strands to the northeast across the shelf using seismic-reflection profiles, and so their presence is based solely on bathymetry. South of the map area, the south strand of the Santa Ynez Fault appears to disperse into a diffuse zone of several shorter, more east-west-striking contractional faults on the outer shelf, and it cannot be traced across the slope into deeper water. This fanlike pattern of faults is characteristic of terminating strike-slip faults (Christie-Blick and Biddle, 1985; Mann, 2007).

In the offshore part of the map area, closely spaced seismic-reflection profiles (see sheet 7) image many shallow, west-northwest-striking folds that have variable geometries, lengths, amplitudes, degrees of continuity, and wavelengths. The two longest folds, the 17-km-long Molino Anticline and the 22-km-long Government Point Syncline (see sheets 8, 9), are truncated to the west and east, respectively, by the south strand of the Santa Ynez Fault. These regionally extensive folds, as well as many other shorter, east-west-striking structures, are probably rooted in blind thrust faults and backthrust faults in the hanging wall above the Pitas Point-North Channel Fault system (fig. 1-3). 
Table 7-1. Areas and relative proportions of offshore geologic map units in Offshore of Gaviota map area.

\begin{tabular}{|c|c|c|c|}
\hline Map Unit & Area $\left(m^{2}\right)$ & Area $\left(\mathbf{k m}^{2}\right)$ & Percent of total area \\
\hline \multicolumn{4}{|c|}{ Marine shelf and upper slope sedimentary units } \\
\hline af & 41,005 & 0.0 & 0.0 \\
\hline aft & $1,116,801$ & 1.1 & 1.1 \\
\hline Qms & $27,854,140$ & 27.9 & 27.4 \\
\hline Qmsc & $6,416,010$ & 6.4 & 6.3 \\
\hline Qmsf & $12,574,410$ & 12.6 & 12.4 \\
\hline Qmsd & 7,111 & 0.0 & 0.0 \\
\hline Qmp & $1,068,996$ & 1.1 & 1.1 \\
\hline Qda & $13,840,013$ & 13.8 & 13.6 \\
\hline Qmsl & $12,246,730$ & 12.2 & 12.0 \\
\hline Qmcr & $3,239,731$ & 3.2 & 3.2 \\
\hline Qmscl & 349,274 & 0.3 & 0.3 \\
\hline Qas & 146,355 & 0.1 & 0.1 \\
\hline Total, shelf sediment units & $78,900,578$ & 78.9 & 77.5 \\
\hline \multicolumn{4}{|c|}{ Marine shelf bedrock and (or) shallow bedrock units } \\
\hline Qms/Tbu & $6,659,611$ & 6.7 & 6.5 \\
\hline Qmsf/Tbu & 448,870 & 0.4 & 0.4 \\
\hline Qms/Tm & 380,191 & 0.4 & 0.4 \\
\hline Qms/Tsq & $2,876,307$ & 2.9 & 2.8 \\
\hline Tbu & $1,030,877$ & 1.0 & 1.0 \\
\hline Tsq & $10,020,526$ & 10.0 & 9.8 \\
\hline $\mathrm{Tm}$ & $1,482,817$ & 1.5 & 1.5 \\
\hline Total, shelf bedrock units & $22,899,198$ & 22.9 & 22.5 \\
\hline Total, Offshore of Gaviota map area & $101,799,775$ & 101.8 & 100.0 \\
\hline
\end{tabular}




\section{DESCRIPTION OF MAP UNITS}

\section{OFFSHORE GEOLOGIC AND GEOMORPHIC UNITS}

[Note that, where older units (typically, bedrock) are overlain by thin $(<1 \mathrm{~m}$ thick) unconsolidated Quaternary deposits, composite units are mapped. These composite units, which are shown with gray or white stipple pattern on older unit, are designated by composite label indicating both overlying sediment cover and lower (older) unit, separated by slash (for example, Qms/Tm indicates that thin sheet of Qms overlies Tm)]

af Artificial seafloor (late Holocene) —Pipelines on inner shelf, south of Gaviota marine terminal

aft Artificially modified seafloor (late Holocene) - Sandy seafloor crossed by very low relief (about 10 to $20 \mathrm{~cm}$ high), widely spaced (about 5 to $15 \mathrm{~m}$ apart), northeast-trending ridges, interpreted as trawling scars; two fields $\left(827,209\right.$ and $\left.289,593 \mathrm{~m}^{2}\right)$ mapped about $3.5 \mathrm{~km}$ south of Gaviota State Park, in water depths of about 40 to $55 \mathrm{~m}$

Qms Marine nearshore and shelf deposits (late Holocene)-Mostly sand; ripples common. Found on gently seaward-dipping $\left(\right.$ about $1^{\circ}$ ) surface that extends from nearshore to water depths of about $55 \mathrm{~m}$ and as prograding low-angle surfaces (for example, clinoforms) on southeast flank of Gaviota sediment bar

Qmsc Coarse-grained marine nearshore and shelf deposits (late Holocene)—Ranges from coarse sand and gravel to boulders. Found mainly on prominent Gaviota sediment bar, oblique bar that extends from mouth of Cañada de la Gaviota to shelf break and also in nearshore (10 to $30 \mathrm{~m}$ water depth) near east edge of map. Recognized primarily on basis of high acoustic-backscatter intensity and positive seafloor relief

Qmsf Fine-grained marine shelf deposits (late Holocene) - Mostly clay, silt, and very fine sand; commonly bioturbated. Found on gently seaward-dipping (about $0.7^{\circ}$ ) shelf, at depths of between about 50 to $70 \mathrm{~m}$ and about $90 \mathrm{~m}$, in southeastern part of map area

Qmsd Marine shelf scour depression (late Holocene) — Inferred to be coarse sand and possibly gravel; consists of irregular, arcuate, low-relief scour depression bounded by bedrock outcrops, along west edge of map area, at water depth of about $35 \mathrm{~m}$

Qmp Marine pockmarks (Holocene) — Sand and mud, in circular to elliptical pockmarks. Pockmarks are solitary or grouped, and they range in size from 50 to $150 \mathrm{~m}$ on their long axis; they typically are 20 to $40 \mathrm{~cm}$ deep and ringed with convex rim as high as $150 \mathrm{~cm}$

Qda Marine shelf slump deposits (Holocene)—Hummocky, sandy debris-flow deposits. Found on southeast flank of Gaviota sediment bar, oblique bar that extends southwestward from mouth of Cañada de la Gaviota to shelf break

Qmsl Marine upper slope deposits (Holocene) — Predominantly clay, silt, and very fine sand; commonly bioturbated. Found below shelf break on seaward-dipping (about $5^{\circ}$ ) slope

Qmer Marine canyons and rills (Holocene) - Probably sand and mud; forms narrow (40 to $300 \mathrm{~m}$ wide), elongate ( 0.5 to $3.7 \mathrm{~km}$ long), and variably shallow (a few meters) to deep (as much as $40 \mathrm{~m}$ ) channels or rills; cut into midshelf to outer shelf and slope. Also includes upper parts of "Alegria Canyon," "Drake Canyon," and "Sacate Canyon" on upper margin of Conception fan (Fischer and Cherven, 1998; Eichhubl and others, 2002)

Qmscl Marine shelf-sediment lobes (Holocene) —Predominantly sand to boulders(?). Found as two distinct, irregularly shaped lobes near east edge of map area about 1,000 to 2,000 $\mathrm{m}$ offshore, at water depths of 35 to $60 \mathrm{~m}$. Lobes, which are more common to east in 
adjacent Offshore of Refugio Beach map area (Conrad and others, 2015), range in size from about 0.1 to about $1.5 \mathrm{~km}^{2}$, and they are mapped on basis of high acousticbackscatter intensity and subtle positive seafloor relief

Qas Asphalt deposits (Holocene) - Asphalt (tar); weathered and biodegraded oil derived from underlying or nearby natural hydrocarbon seeps. Found along and near axis of Molino Anticline

Tbu Bedrock, undivided (Pliocene and Miocene) - Mainly mudstone and siltstone. Probably consists of the Pliocene Pico and Repetto Formations, the lower Pliocene and upper Miocene Sisquoc Formation, and the Miocene Monterey Formation. Stippled areas are composite units where thin sheets of sediment (either Qms or Qmsf) overlie bedrock: gray stipple indicates composite unit $\mathrm{Qms} / \mathrm{Tbu}$, and white stipple indicates composite unit Qmsf/Tbu

Tsq Sisquoc Formation (early Pliocene and late Miocene) - Marine, tan- to white-weathering, diatomaceous mudstone and shale, conglomerate, and subordinate dolomite. Stippled areas (composite unit $\mathrm{Qms} / \mathrm{Tsq}$ ) indicate where thin sheets of $\mathrm{Qms}$ overlie unit

Tm Monterey Formation (Miocene)—Predominantly well-bedded, siliceous and calcareous mudstone and shale. Stippled areas (composite unit $\mathrm{Qms} / \mathrm{Tm}$ ) indicate where thin sheets of Qms overlie unit

\section{ONSHORE GEOLOGIC AND GEOMORPHIC UNITS}

[Units compiled from Dibblee (1988a,b); unit ages, which are from these sources, reflect local stratigraphic relations. In addition, some Quaternary units modified by C.W. Davenport on basis of analysis of 2004 ifSAR and 2009 lidar imagery]

af

Qb

Qsc

\section{Qya}

Qal

Qyf

Qc

Qls

Qa

Artificial fill (late Holocene) - Engineered and (or) nonengineered material deposited by humans

Beach deposits (late Holocene) - Unconsolidated, loose, fine- to coarse-grained sand, pebbles, and boulders; well sorted. Mapped in coastal band from shoreline to highest elevation of swash zone; may consist of thin veneer over bedrock platform

Active stream-channel deposits (late Holocene) - Active stream channels that contain unconsolidated sand, silt, and gravel deposits

Alluvium (late Holocene) - Alluvial deposits adjacent to active stream channels

Alluvial deposits, undivided (Holocene) - Sand, gravel, and silt deposits, adjacent to or near active stream channels. Locally, may include stream-terrace and -channel deposits too small to delineate at map scale

Alluvial fan deposits (Holocene) - Unconsolidated, heterogeneous layers of sand, silt, and gravel; relatively undissected; deposited by streams emanating from canyons onto alluvial plains; identified primarily by fan morphology and topographic expression. Internal contacts delineate individual alluvial fans

Colluvium (Holocene) - Loose to firm, unsorted sand, silt, clay, gravel, rock debris, and organic material; includes slope wash and valley fill; may contain numerous small landslides and (or) coalesced alluvial fans

Landslide deposits (Holocene and Pleistocene)—Deposits of diverse slope-movement processes; ranges from poorly sorted, disrupted mixtures of rock fragments and soil to relatively intact bedrock slump blocks; queried where identity is uncertain. Internal contacts delineate individual landslide bodies

Alluvial deposits, undivided (Holocene and Pleistocene) — Sand, gravel, and silt deposits . Mapped on gently sloping to level surfaces near stream channels, where relative ages are uncertain or where separate units could not be delineated at map scale 
Qf Alluvial fan deposits (Holocene and Pleistocene) - Poorly consolidated silt, sand, and gravel deposits. Mapped either where older age is indicated by greater degree of dissection or where elevations are higher than that of adjacent Holocene alluvial fans. Internal contacts delineate individual alluvial fans

Qoa Alluvial deposits (Pleistocene) - Sand, gravel, and silt deposits; includes remnants of stream terraces and alluvial fans

Qof Alluvial fan deposits (Pleistocene) - Discontinuous or highly dissected deposits of semiconsolidated, moderately to poorly sorted layers of silty clay, silt, sand, and gravel. Found adjacent to mountain fronts

Qg Gravel, cobbles, and boulders (Pleistocene) - Fan and fanglomerate deposits that consist of gravel, cobbles, and boulders

Qmt Marine-terrace deposits, undivided (Pleistocene) - Semiconsolidated sand and local gravel deposits, on uplifted marine-abrasion platforms along coast; locally, may include fluvial and (or) colluvial deposits too small to delineate at map scale

Tsq Sisquoc Formation (early Pliocene and late Miocene) - Marine shale, claystone, and diatomite

Tm Monterey Formation, undivided (Miocene) - Marine, predominantly well-bedded, siliceous chert, mudstone, shale, diatomite, and conglomerate breccia. Locally divided into three subunits that are distinguished by stratigraphic position, lithology, and (or) age

Tmcg Conglomerate breccia (Miocene) — Siliceous and cherty shale detritus in tar-soaked sandstone matrix

Tml

Tmls

$\mathrm{Tt}$

$\operatorname{Tr}$

TV

Tvsc

Tsp

Tspc

$\mathrm{Ta}$

$\operatorname{Tg}$

Tgs

Tg-sa

Ts

Tss

Tcd

Tma

Tan

Light-gray diatomite (Miocene)

Semisiliceous shale (Miocene)

Tranquillon Volcanics (Miocene) - Rhyolitic tuff breccia

Rincon Shale (early Miocene)-Marine shale or claystone

Vaqueros Formation (late Oligocene) - Marine calcareous sandstone; queried where identity is uncertain. Includes one subunit

Sandstone and pebble conglomerate (late Oligocene)

Sespe Formation, upper sandstone and mudstone unit (Oligocene)-Nonmarine sandstone, siltstone, and mudstone. Includes one subunit

Sandstone and pebble conglomerate (Oligocene)

Alegria Formation (Oligocene) - Marine arkosic sandstone and silty claystone; queried where identity is uncertain

Gaviota Formation (Oligocene and Eocene) - Marine arkosic sandstone, locally fossiliferous. Includes one subunit

Concretionary siltstone and claystone (Oligocene and Eocene) - Queried where identity is uncertain

Gaviota Formation and Sacate Formation, undivided (Oligocene and Eocene) —-Marine sandstone and siltstone

Sacate Formation (Eocene) - Marine arkosic sandstone that contains interbeds of micaceous, clayey shale. Includes one subunit

Predominantly shale (late Eocene)

Cozy Dell Shale (Eocene) - Marine micaceous shale

Matilija Sandstone (Eocene) — Marine arkosic sandstone; queried where identity is uncertain

Anita Shale (Eocene and Paleocene) - Marine, micaceous, clayey shale; includes foraminiferal claystone (informally known as "Poppin shale") 
Kja Jalama Formation (Late Cretaceous) - Marine arkosic sandstone. Includes three subunits Siltstone (Late Cretaceous)

Micaceous shale and siltstone (Late Cretaceous)

Kjss

Arkosic sandstone and interbeds of micaceous shale (Late Cretaceous) 


\section{Acknowledgments}

This publication was funded by the California Ocean Protection Council and the U.S. Geological Survey (USGS) Coastal and Marine Geology Program. We thank Robert Garrison (University of California, Santa Cruz) and Robert Peters (USGS) for their critical reviews that greatly improved this report. We are grateful to USGS editor Taryn Lindquist for helping us develop the templates and formats for this series of publications, and for invaluable editorial review and suggestions. 


\section{References Cited}

Briggs, J.C., 1974, Marine zoogeography: New York, McGraw-Hill, 480 p.

Cacchione, D.A., Drake, D.E., Grant, W.D., and Tate, G.B., 1984, Rippled scour depressions of the inner continental shelf off central California: Journal of Sedimentary Petrology, v. 54, p. 1,280-1,291.

California Department of Fish and Wildlife, 2008, California Marine Life Protection Act master plan for marine protected areas-Revised draft: California Department of Fish and Wildlife [formerly California Department of Fish and Game], available at https://www.wildlife.ca.gov/Conservation/ Marine/MPAs/Master-Plan.

California State University, Monterey Bay, Seafloor Mapping Lab, 2016, Southern California 2008 CSMP surveys: California State University, Monterey Bay, Seafloor Mapping Lab Data Library, accessed October 2016 at http://seafloor.otterlabs.org/SFMLwebDATA_SURVEYMAP.htm.

Chaytor, J.D., Goldfinger, C., Meinter, M.A., Huftile, G.J., Rosmos, C.G., and Legg, M.R., 2008, Measuring vertical tectonic motion at the intersection of the Santa Cruz-Santa Catalina Ridge and Northern Channel Islands platform, California Continental Borderland, using submerged paleoshorelines: Geological Society of America Bulletin, v. 120, p. 1,053-1,071.

Christie-Blick, N., and Biddle, K.T., 1985, Deformation and basin formation along strike-slip faults, in Biddle, K.T., and Christie-Blick, N., eds., Strike-slip deformation, basin formation, and sedimentation: Society of Economic Paleontologists and Mineralogists Special Publication 37, p. 1-34.

Cochrane, G.R., 2008, Video-supervised classification of sonar data for mapping seafloor habitat, in Reynolds, J.R., and Greene, H.G., eds., Marine habitat mapping technology for Alaska: Fairbanks, University of Alaska, Alaska Sea Grant College Program, p. 185-194, available at http://doc.nprb.org/web/research/research\%20pubs/615_habitat_mapping_workshop/Individual\%20C hapters\%20High-Res/Ch13\%20Cochrane.pdf.

Cochrane, G.R., Conrad, J.E., Reid, J.A., Fangman, S., and Golden, N., 2005, Nearshore benthic habitat GIS for the Channel Islands National Marine Sanctuary and southern California state fisheries reserves, vol. II: U.S. Geological Survey Open-File Report 2005-1170, available at https://pubs.usgs.gov/of/2005/1170/.

Cochrane, G.R., Nasby, N.M., Reid, J.A., Waltenberger, B., and Lee, K.M., 2003, Nearshore benthic habitat GIS for the Channel Islands National Marine Sanctuary and southern California state fisheries reserves, vol. I: U.S. Geological Survey Open-File Report 03-85, available at https://pubs.usgs.gov/of/2003/0085/.

Conrad, J.E., Ritchie, A.C., Johnson, S.Y., Seitz, G.G., and Gutierrez, C.I., 2015, Offshore and onshore geology and geomorphology, Offshore of Refugio Beach map area, California, sheet 10 in Johnson, S.Y., Dartnell, P., Cochrane, G.R., Golden, N.E., Phillips, E.L., Ritchie, A.C., Krigsman, L.M., Dieter, B.E., Conrad, J.E., Greene, H.G., Seitz, G.G., Endris, C.A., Sliter, R.W., Wong, F.L., Erdey, M.D., Gutierrez, C.I., Yoklavich, M.M., East, A.E., and Hart, P.E. (S.Y. Johnson and S.A. Cochran, eds.), California State Waters Map Series_-Offshore of Refugio Beach, California: U.S. Geological Survey Scientific Investigations Map 3319, pamphlet 42 p., 11 sheets, scale 1:24,000, available at https://pubs.usgs.gov/sim/3319/.

County of Santa Barbara, Planning and Development, Energy Division, 2016, Gaviota Terminal abandonment: County of Santa Barbara, Planning and Development, Energy Division website, accessed October 13, 2016, at http://www.sbcountyplanning.org/energy/projects/gaviotaAbandon.asp.

Cudaback, C.N., Washburn, L., and Dever, E., 2005, Subtidal inner-shelf circulation near Point Conception, California: Journal of Geophysical Research, v. 110, C10007, 12 p., available at https://doi.org/10.1029/2004JC002608. 
Davis, A.C.D., Kvitek, R.G., Mueller, C.B.A., Young, M.A., Storlazzi, C.D., and Phillips, E.L., 2013, Distribution and abundance of rippled scour depressions along the California coast: Continental Shelf Research, v. 69, p. 88-100, available at https://doi.org/10.1016/j.csr.2013.09.010.

Dibblee, T.W., Jr., 1950, Geology of southwestern Santa Barbara County, California, Point Arguello, Lompoc, Point Conception, Los Olivos, and Gaviota quadrangles: California Division of Mines and Geology Bulletin 150, 95 p., scale 1:62,500.

Dibblee, T.W., Jr., 1988a, Geologic map of the Santa Rosa Hills and Sacate quadrangles, Santa Barbara County, California (H.E. Ehrenspeck, ed. [1988]): Dibblee Geological Foundation Map DF-17, scale $1: 24,000$.

Dibblee, T.W., Jr., 1988b, Geologic map of the Solvang and Gaviota quadrangles, Santa Barbara County, California (H.E. Ehrenspeck, ed. [1988]): Dibblee Geological Foundation Map DF-16, scale $1: 24,000$.

Draut, A.E., Hart, P.E., Lorenson, T.D., Ryan, H.F., Wong, F.L., Sliter, R.W., and Conrad, J.E., 2009, Late Pleistocene to Holocene sedimentation and hydrocarbon seeps on the continental shelf of a steep, tectonically active margin, southern California, USA: Marine Geophysical Research, p. 193-206, available at https://doi.org/10.1007/s11001-009-9076-y.

Duvall, A., Kirby, E., and Burbank, D., 2004, Tectonic and lithologic controls on bedrock channel profiles and processes in coastal California: Journal of Geophysical Research, v. 109, 18 p., F03002, available at https://doi.org/10.1029/2003JF000086,2004.

Eichhubl, P., Greene, H.G., and Maher, N., 2002, Physiography of an active transpressive margin basin-High-resolution bathymetry of the Santa Barbara basin, southern California continental borderland: Marine Geology, v. 184, p. 95-120.

Fader, G.B.J., 1997, Effects of shallow gas on seismic-reflection profiles, in Davies, T.A., Bell, T., Cooper, A.K., Josenhaus, H., Polyak, L., Solheim, A., Stoker, M.S., and Stravers, J.A., eds., Glaciated continental margins - An atlas of acoustic images: London, Chapman \& Hall, p. 29-30.

Fischer, P.J., 1998, Structure and tectonics of northwestern Santa Barbara basin, in Kunitomi, D.S., Hopps, T.E., and Galloway, J.M., eds., Structure and petroleum geology, Santa Barbara Channel, California: American Association of Petroleum Geologists, Pacific Section, and Coast Geological Society, Miscellaneous Publication 46, p, 79-96.

Fischer, P.J., and Cherven, B.B., 1998, The Conception Fan, Santa Barbara Basin, California, in Kunitomi, D.S., Hopps, T.E., and Galloway, J.M., eds., Structure and petroleum geology, Santa Barbara Channel, California: American Association of Petroleum Geologists, Pacific Section, and Coast Geological Society, Miscellaneous Publication 46, p, 155-181.

Fisher, M.A., Normark, W.R., Greene, H.G., Lee, H.J., and Sliter, R.W., 2005, Geology and tsunamigenic potential of submarine landslides in Santa Barbara Channel, southern California: Marine Geology, v. 224, p. 1-22.

Fisher, M.A., Sorlien, C.C., and Sliter, R.W., 2009, Potential earthquake faults offshore southern California from the eastern Santa Barbara channel to Dana Point, in Lee, H.J., and Normark, W.R., eds., Earth science in the urban ocean-The Southern California Continental Borderland: Geological Society of America Special Paper 454, p. 271-290.

Galloway, J.M., 1998, Chronology of petroleum exploration and development in the Santa Barbara channel area, offshore southern California, in Kunitomi, D.S., Hopps, T.E., and Galloway, J.M., eds., Structure and petroleum geology, Santa Barbara Channel, California: American Association of Petroleum Geologists, Pacific Section, and Coast Geological Society, Miscellaneous Publication 46, p. $1-12,1$ sheet.

Goff, J.A., Mayer, L.A., Traykovski, P., Buynevich, I., Wilkens, R., Raymond, R., Glang, G., Evans, R.L., Olson, H., and Jenkins, C., 2005, Detailed investigations of sorted bedforms or "rippled scour 
depressions," within the Martha's Vineyard Coastal Observatory, Massachusetts: Continental Shelf Research, v. 25, p. 461-484.

Golden, N.E., and Cochrane, G.R., 2013, California Seafloor Mapping Program video and photograph portal: U.S. Geological Survey, Coastal and Marine Geology Program data portal, available at https://doi.org/10.5066/F7J1015K.

Greene, H.G., and Bizzarro, J.J., 2003, Essential fish habitat characterization and mapping of the California continental margin: Final Report to Pacific States Marine Fisheries Commission, CFDA \#11-454, 14 p., available at http://marinehabitat.psmfc.org/files/source_docs/

EFH_report_with_Appendices.pdf.

Greene, H.G., Bizzarro, J.J., O’Connell, V.M., and Brylinsky, C.K., 2007, Construction of digital potential marine benthic habitat maps using a coded classification scheme and its application, in Todd, B.J., and Greene, H.G., eds., Mapping the seafloor for habitat characterization: Geological Association of Canada Special Paper 47, p. 141-155.

Greene, H.G., Murai, L.Y., Watts, P., Maher, N.A., Fisher, M.A., and Eichhubl, P., 2006, Submarine landslides in the Santa Barbara channel as potential tsunami sources: Natural Hazards and Earth System Sciences, v. 6, p. 63-88.

Greene, H.G., Yoklavich, M.M., Starr, R.M., O’Connell, V.M., Wakefield, W.W., Sullivan, D.E., McRea, J.E., and Cailliet, G.M., 1999, A classification scheme for deep seafloor habitats: Oceanologica Acta, v. 22, p. 663-678.

Griggs, G., Patsch, K., and Savoy, L., 2005, Living with the changing California coast: Berkeley, University of California Press, $540 \mathrm{p}$.

Gurrola, L.D., Keller, E.A., Chen, J.H., Owen, L.A., and Spencer, J.Q., 2014, Tectonic geomorphology of marine terraces - Santa Barbara fold belt, California: Geological Society of America Bulletin, v. 126, p. 219-233.

Hallenbeck, T.R., Kvitek, R.G., and Lindholm, J., 2012, Rippled scour depressions add ecologically significant heterogeneity to soft-bottom habitats on the continental shelf: Marine Ecology Progress Series, v. 468, p. 119-133, available at https://doi.org/10.3354/meps09948.

Hapke, C.J., and Reid, D.R., 2007, National assessment of shoreline change, part 4-Historical coastal cliff retreat along the California Coast: U.S. Geological Survey Open-File Report 2007-1133, 51 p., available at https://pubs.usgs.gov/of/2007/1133/.

Hapke, C.J., Reid, D., Richmond, B.B., Ruggiero, P., and List, J., 2006, National assessment of shoreline change, part 3-Historical shoreline change and associated coastal land loss along sandy shorelines of the California coast: U.S. Geological Survey Open-File Report 2006-1219, 72 p., available at https://pubs.usgs.gov/of/2006/1219/.

Heck, R.G., 1998, Santa Barbara Channel regional formline map, top Monterey Formation, in Kunitomi, D.S., Hopps, T.E., and Galloway, J.M., eds., Structure and petroleum geology, Santa Barbara Channel, California: American Association of Petroleum Geologists, Pacific Section, and Coast Geological Society, Miscellaneous Publication 46, 1 plate.

Hornafius, J.S., Luyendyk, B.P., Terres, R.R., and Kamerling, M.J., 1986, Timing and extent of Neogene rotation in the western Transverse Ranges, California: Geological Society of America Bulletin, v. 97, p. 1,476-1,487.

Hovland, M., and Judd, A.G., 1988, Seabed pockmark and seepages: London, Graham and Trotman, Inc., 293 p.

Jennings, C.W., and Bryant, W.A., 2010, Fault activity map of California: California Geological Survey Geologic Data Map No. 6, scale 1:750,000, available at http://www.conservation.ca.gov/cgs/ cgs_history/Pages/2010_faultmap.aspx.

Johnson, S.Y., Cochrane, G.R., Golden, N.E., Dartnell, P., Hartwell, S.R., Cochran, S.A., and Watt, J.T., 2017, The California Seafloor and Coastal Mapping Program_-Providing science and geospatial data 
for California's State Waters: Ocean and Coastal Management, v. 140, p. 88-104, available at https://doi.org/10.1016/j.ocecoaman.2017.02.004.

Johnson, S.Y., Dartnell, P., Cochrane, G.R., Golden, N.E., Phillips, E.L., Ritchie, A.C., Greene, H.G., Krigsman, L.M., Kvitek, R.G., Dieter, B.E., Endris, C.A., Seitz, G.G., Sliter, R.W., Erdey, M.E., Gutierrez, C.I., Wong, F.L., Yoklavich, M.M., Draut, A.E., Hart, P.E., and Conrad, J.E. (S.Y. Johnson and S.A. Cochran, eds.), 2013a, California State Waters Map Series-Offshore of Santa Barbara, California: U.S. Geological Survey Scientific Investigations Map 3281, pamphlet 45 p., 11 sheets, scale 1:24,000, available at https://pubs.usgs.gov/sim/3281/.

Johnson, S.Y., Dartnell, P., Cochrane, G.R., Golden, N.E., Phillips, E.L., Ritchie, A.C., Krigsman, L.M., Dieter, B.E., Conrad, J.E., Greene, H.G., Seitz, G.G., Endris, C.A., Sliter, R.W., Wong, F.L., Erdey, M.D., Gutierrez, C.I., Yoklavich, M.M., East, A.E., and Hart, P.E. (S.Y. Johnson and S.A. Cochran, eds.), 2015, California State Waters Map Series - Offshore of Refugio Beach, California: U.S. Geological Survey Scientific Investigations Map 3319, pamphlet 42 p., 11 sheets, scale 1:24,000, available at https://pubs.usgs.gov/sim/3319/.

Johnson, S.Y., Dartnell, P., Cochrane, G.R., Golden, N.E., Phillips, E.L., Ritchie, A.C., Kvitek, R.G., Dieter, B.E., Conrad, J.E., Lorenson, T.D., Krigsman, L.M., Greene, H.G., Endris, C.A., Seitz, G.G., Finlayson, D.P., Sliter, R.W., Wong, F.L., Erdey, M.D., Gutierrez, C.I., Leifer, I., Yoklavich, M.M., Draut, A.E., Hart, P.E., Hostettler, F.D., Peters, K.E., Kvenvolden, K.A., Rosenbauer, R.J., and Fong, G. (S.Y. Johnson and S.A. Cochran, eds.), 2014, California State Waters Map Series-Offshore of Coal Oil Point, California: U.S. Geological Survey Scientific Investigations Map 3302, pamphlet 57 p., 12 sheets, scale 1:24,000, available at https://pubs.usgs.gov/sim/3302/.

Johnson, S.Y., Dartnell, P., Cochrane, G.R., Golden, N.E., Phillips, E.L., Ritchie, A.C., Kvitek, R.G., Greene, H.G., Endris, C.A., Seitz, G.G., Sliter, R.W., Erdey, M.D., Wong, F.L., Gutierrez, C.I., Krigsman, L.M., Draut, A.E., and Hart, P.E. (S.Y. Johnson and S.A. Cochran, eds.), 2013c, California State Waters Map Series - Offshore of Carpinteria, California: U.S. Geological Survey Scientific Investigations Map 3261, pamphlet 42 p., 10 sheets, available at http://pubs.usgs.gov/sim/3261/. Johnson, S.Y., Dartnell, P., Cochrane, G.R., Golden, N.E., Phillips, E.L., Ritchie, A.C., Kvitek, R.G., Greene, H.G., Krigsman, L.M., Endris, C.A., Clahan, K.B., Sliter, R.W., Wong, F.L., Yoklavich, M.M., and Normark, W.R. (S.Y. Johnson, ed.), 2012, California State Waters Map Series-Hueneme Canyon and vicinity, California: U.S. Geological Survey Scientific Investigations Map 3225, pamphlet 41 p., 12 sheets, scale 1:24,000, available at http://pubs.usgs.gov/sim/3225/.

Johnson, S.Y., Dartnell, P., Cochrane, G.R., Golden, N.E., Phillips, E.L., Ritchie, A.C., Kvitek, R.G., Greene, H.G., Krigsman, L.M., Endris, C.A., Seitz, G.G., Gutierrez, C.I., Sliter, R.W., Erdey, M.D., Wong, F.L., Yoklavich, M.M., Draut, A.E., and Hart, P.E. (S.Y. Johnson and S.A. Cochran, eds.), 2013b, California State Waters Map Series-Offshore of Ventura, California: U.S. Geological Survey Scientific Investigations Map 3254, pamphlet 42 p., 11 sheets, scale, 1:24,000, available at http://pubs.usgs.gov/sim/3254/.

Johnson, S.Y., Dartnell, P., Cochrane, G.R., Hartwell, S.R., Golden, N.E., Kvitek, R.G., and Davenport, C.W. (S.Y. Johnson and S.A. Cochran, eds.), 2018, California State Waters Map Series-Offshore of Point Conception, California: U.S. Geological Survey Open-File Report 2018-1024, pamphlet 36 p., 9 sheets, scale 1:24,000, available at https://doi.org/10.3133/ofr20181024.

Johnson, S.Y., Hartwell, S.R., and Beeson, J.W., 2016, Marine geophysical data-Point Sal to Refugio State Beach, southern California: U.S. Geological Survey data release, available at https://doi.org/10.5066/F7SX6BCD.

Keller, E.A., Duffy, M., Kennett, J.P., and Hill, T., 2007, Tectonic geomorphology and hydrocarboninduced topography of the mid-Channel anticline, Santa Barbara basin, California: Geomorphology, v. 89, p. 274-286. 
Kunitomi, D.S., Hopps, T.E., and Galloway, J.M., eds., 1998, Structure and petroleum geology, Santa Barbara Channel, California: American Association of Petroleum Geologists, Pacific Section, and Coast Geological Society, Miscellaneous Publication 46, 328 p.

Kvitek, R., Bretz, C., Cochrane, G.R., and Greene, H.G., 2006, Final report, Statewide Marine Mapping Planning Workshop, December 12-13, 2005, Seaside, Calif.: California State University, Monterey Bay, 108 p., available at http://www.opc.ca.gov/webmaster/ftp/project_pages/mapping/2005 FINAL mapping report April 2006.pdf.

Larson, K.M., and Webb, F.H., 1992, Deformation in the Santa Barbara Channel from GPS measurements 1987-1991: Geophysical News Letters, v. 19, p. 1,491-1,494.

Lee, H.J., Greene, H.G., Edwards, B.D., Fisher, M.A., and Normark, W.R., 2009, Submarine landslides in the southern California borderland, in Lee, H.J., and Normark, W.R., eds., Earth science in the urban ocean-The Southern California Continental Borderland: Geological Society of America Special Paper 454, p. 251-269.

Lee, H.J., and Normark, W.R., eds., 2009, Earth science in the urban ocean-The Southern California Continental Borderland: Geological Society of America Special Paper 454, 481 p.

Lee, W.H.K., and Vedder, J.G., 1973, Recent earthquake activity in the Santa Barbara Channel region: Bulletin of the Seismological Society of America, v. 63, p. 1,757-1,773.

Lorenson, T.L., Wong, F.L., Dartnell, P., and Sliter, R.W., 2014, Greenhouse gases generated from the anaerobic biodegradation of natural offshore asphalt seepages in southern California: Geo-Marine Letters, v. 34, p. 281-295, available at https://doi.org/10.1007/s00367-014-0359-1.

Luyendyk, B.P., Kamerling, M.J., and Terres, R.R., 1980, Geometric model for Neogene crustal rotations in southern California: Geological Society of America Bulletin, v. 91, p. 211-217.

Madden, C.J., Goodin, K.L., Allee, R., Finkbeiner, M., and Bamford, D.E., 2008, Draft Coastal and Marine Ecological Classification Standard: National Oceanic and Atmospheric Administration (NOAA) and NatureServe, v. III, 77 p.

Mann, P., 2007, Global catalogue, classification, and tectonic origin of restraining and releasing bends on active and ancient strike-slip fault systems, in Cunningham, W.D., and Mann, P., eds., Tectonics of strike-slip restraining and releasing bends: London, Geological Society of London, Special Publication 290, p. 13-142.

Marshall, S.T., Funning, G.J., and Owen, S.E., 2013, Fault slip rates and interseismic deformation in the western Transverse Ranges, California: Journal of Geophysical Research, v. 118, 24 p., available at https://doi.org/10.1002/jgrb.50312.

Metcalf, J.G., 1994, Morphology, chronology, and deformation of Pleistocene marine terraces, southwestern Santa Barbara County, Santa Barbara, California: Santa Barbara, University of California, Santa Barbara, M.S. thesis, 168 p.

Minor, S.A., Kellogg, K.S., Stanley, R.G., Gurrola, L.D., Keller, E.A., and Brandt, T.R., 2009, Geologic map of the Santa Barbara coastal plain area, Santa Barbara County, California: U.S. Geological Survey Scientific Investigations Map 3001, scale 1:25,000, 1 sheet, pamphlet 38 p., available at http://pubs.usgs.gov/sim/3001/.

Mitchum, R.M., Jr., Vail, P.R., and Sangree, J.B., 1977, Seismic stratigraphy and global changes of sea level, part 6-Stratigraphic interpretation of seismic reflection patterns in depositional sequences, in Payton, C.E., ed., Seismic stratigraphy_-Applications to hydrocarbon exploration: Tulsa, Okla., American Association of Petroleum Geologists, p. 117-133.

Muhs, D.R., Rockwell, T.K., and Kennedy, G.L., 1992, Late Quaternary uplift rates of marine terraces on the Pacific Coast of North America, southern Oregon to Baja California Sur: Quaternary International, v. 15/16, p. 121-133. 
Murray, A.B., and Thieler, E.R., 2004, A new hypothesis and exploratory model for the formation of large-scale inner-shelf sediment sorting and "rippled scour depressions:" Continental Shelf Research, v. 24, no. 3, p. 295-315.

National Geodetic Survey, 2016, NOAA Shoreline Data Explorer: National Oceanic and Atmospheric Administration, National Geodetic Survey data viewer and database, accessed May 1, 2016, at http://www.ngs.noaa.gov/NSDE/.

National Oceanic and Atmospheric Administration, 2013, 2013 NOAA Coastal California TopoBathy Merge Project: National Oceanic and Atmospheric Administration, National Centers for Environmental Information database, accessed October 2016 at http:/www.ngdc.noaa.gov/docucomp/ page?xml=NOAA/NESDIS/NGDC/MGG/Lidar/iso/xml/2013_CA_TopoBathy_m2612.xml\&view=ge tDataView\&header=none.

Nicholson, C., Sorlien, C., Atwater, T., Crowell, J.C., and Luyendyk, B.P., 1994, Microplate capture, rotation of the western Transverse Ranges, and initiation of the San Andreas transform as a low-angle fault system: Geology, v. 22, p. 491-495.

O'Reilly, W.C., and Guza, R.T., 1993, A comparison of spectral wave models in the Southern California Bight: Coastal Engineering, v. 19, p. 263-282, available at https://doi.org/10.1016/03783839(93)90032-4.

Peltier, W.R., and Fairbanks, R.G., 2006, Global glacial ice volume and Last Glacial Maximum duration from an extended Barbados sea level record: Quaternary Science Reviews, v. 25, p. 3,322-3,337.

Petersen, M.D., Moschetti, M.P., Powers, P.M., Mueller, C.S., Haller, K.M., Frankel, A.D., Zeng, Y., Rezaeian, S., Harmsen, S.C., Boyd, O.S., Field, N., Chen, R., Rukstales, K.S., Luco, N., Wheeler, R.L., Williams, R.A., and Olsen, A.H., 2014, Documentation for the 2014 update of the United States national seismic hazard maps: U.S. Geological Survey Open-File Report 2014-1091, 243 p., available at https://doi.org/10.3133/ofr20141091.

Redin, T., Forman, J., Kamerling, M., and Galloway, J., 2005, Santa Barbara Channel structure and correlation sections-CS-32 to CS-42: American Association of Petroleum Geologists, Pacific Section, Publication CS 36, 12 sheets.

Reid, J.A., Reid, J.M., Jenkins, C.J., Zimmerman, M., Williams, S.J., and Field, M.E., 2006, usSEABED_Pacific Coast (California, Oregon, Washington) offshore surficial-sediment data release: U.S. Geological Survey Data Series 182, available at http://pubs.usgs.gov/ds/2006/182/.

Rockwell, T.K., Nolan, J., Johnson, D.L., and Patterson, R.H., 1992, Ages and deformation of marine terraces between Point Conception and Gaviota, Western Transverse Ranges, California, in Wehmiller, J.F., and Fletcher, C., eds., Quaternary coasts of the United States-Marine and lacustrine systems: Society of Economic Paleontologists and Mineralogists, p. 333-341.

Slater, R.A., Gorsline, D.S., Kolpack, R.L., and Shiller, G.I., 2002, Post-glacial sediments of the California shelf from Cape San Martin to the US-Mexico border: Quaternary International, v. 92, p. 45-61.

Sommerfield, C.R., Lee, H.J., and Normark, W.R., 2009, Postglacial sedimentary record of the southern California continental shelf and slope, Point Conception to Dana Point, in Lee, H.J., and Normark, W.R., eds., Earth science in the urban ocean-The Southern California Continental Borderland: Geological Society of America Special Paper 454, p. 89-116.

Sorlien, C.C., Kamerling, M.J., Seeber, L., and Broderick, K.G., 2006. Restraining segments and reactivation of the Santa Monica-Dume-Malibu Coast fault system, offshore Los Angeles, California: Journal of Geophysical Research, Solid Earth, v. 11, 22 p.

Sorlien, C.C., and Nicholson, C., 2015, Post 1-Ma deformation history of the Pitas Point-North ChannelRed Mountain fault system and associated folds in Santa Barbara channel, California: U.S. Geological Survey National Earthquake Hazards Reduction Program final report, Award G14AP00012, 24 p., available at https://earthquake.usgs.gov/cfusion/external_grants/reports/G14AP00012.pdf. 
Stanford, J.D., Hemingway, R., Rohling, E.J., Challenor, P.G., Medina-Elizalde, M., and Lester, A.J., 2011, Sea-level probability for the last deglaciation-A statistical analysis of far-field records: Global and Planetary Change, v. 79, p. 193-203, available at https://doi.org/10.1016/j.gloplacha.2010.11.002.

Steel, E., Simms, A., Warrick, J., and Yokoyama, Y., 2015, Depositional history and stratigraphic architecture of lofted hyperpycnal flows in the Santa Barbara Channel, southern California [abs.]: American Association of Petroleum Geologists, Pacific Section, Convention, Oxnard, Calif., May 36, 2015, available at http://www.searchanddiscovery.com/abstracts/html/2015/90215pacsec/abstracts/ S02.0.03.html.

Stover, C.W., and Coffman, J.L., 1993, Seismicity of the United States, 1568-1989 (revised): U.S. Government Printing Office, $418 \mathrm{p}$.

Sylvester, A.G., 2001, Catalog of Santa Barbara earthquakes - 1800 to 1960: Santa Barbara, University of California, Santa Barbara database, accessed March 2016 at http://projects.crustal.ucsb.edu/sb_eqs/ SBEQCatlog/SBEQCATINTRO.html.

Sylvester, A.G., Smith, S.S., and Scholz, C.H., 1970, Earthquake swarm in the Santa Barbara Channel, California, 1968: Bulletin of the Seismological Society of America, v. 60, p. 1,047-1,060.

Tennyson, M.E., and Kropp, A.P., 1998, Regional cross section across Santa Barbara channel from northwestern Santa Rosa Island to Canada de Molina, in Kunitomi, D.S., Hopps, T.E., and Galloway, J.M., eds., Structure and petroleum geology, Santa Barbara Channel, California: American Association of Petroleum Geologists, Pacific Section, and Coast Geological Society, Miscellaneous Publication 46, 1 plate.

Trembanis, A.C., and Hume, T.M., 2011, Sorted bedforms on the inner shelf off northeastern New Zealand - Spatiotemporal relationships and potential paleo-environmental implications: Geo-Marine Letters, v. 31, p. 203-214, available at https://doi.org/10.1007/s00367-010-0225-8.

Triezenberg, P.J., Hart, P.E., and Childs, J.R., 2016, National Archive of Marine Seismic Surveys (NAMSS) - A USGS data website of marine seismic reflection data within the U.S. Exclusive Economic Zone (EEZ): U.S. Geological Survey data release, accessed June 29, 2015, at https://doi.org/10.5066/F7930R7P [formerly U.S. Geological Survey’s National Archive of Marine Seismic Surveys database, available at http://walrus.wr.usgs.gov/NAMSS/].

U.S. Geological Survey, 2016, Earthquake catalog: U.S. Geological Survey database, accessed June 14, 2016, at https://earthquake.usgs.gov/earthquakes/search/.

U.S. Geological Survey and California Geological Survey, 2016, Quaternary fault and fold database of the United States: U.S. Geological Survey database, accessed October 4, 2016, at http://earthquake.usgs.gov/hazards/qfaults/.

Warrick, J.A., and Farnsworth, K.L., 2009, Sources of sediment to the coastal waters of the Southern California Bight, in Lee, H.J., and Normark, W.R., eds., Earth science in the urban ocean-The Southern California Continental Borderland: Geological Society of America Special Paper 454, p. 3952.

Warrick, J.A., and Mertes, L.A.K., 2009, Sediment yield from the tectonically active semiarid Western Transverse Ranges of California: Geological Society of America Bulletin, v. 121, p. 1,054-1,070. Warrick, J.A., Simms, A.R., Ritchie, A., Steel, E., Dartnell, P., Conrad, J., and Finlayson, D.P., 2013, Hyperpycnal plume-derived fans in the Santa Barbara Channel, California: Geophysical Research Letters, v. 40, p. 2,081-2,086.

Wong, F.L., Phillips, E.L., Johnson, S.Y, and Sliter, R.W., 2012, Modeling of depth to base of Last Glacial Maximum and seafloor sediment thickness for the California State Waters Map Series, eastern Santa Barbara Channel, California: U.S. Geological Survey Open-File Report 2012-1161, 16 p., available at http://pubs.usgs.gov/of/2012/1161/.

Wright, D.J., Pendleton, M., Boulware, J., Walbridge, S., Gerlt, B., Eslinger, D., Sampson, D., and Huntley, E., 2012, ArcGIS Benthic Terrain Modeler (BTM), v. 3.0: Environmental Systems Research 
Institute, NOAA Coastal Services Center, Massachusetts Office of Coastal Zone Management, accessed March 2016 at http://esriurl.com/5754.

Xu, J.P., and Noble, M.A., 2009, Variability of the southern California wave climate and implications for sediment transport, in Lee, H.J., and Normark, W.R., eds., Earth science in the urban ocean-The Southern California Continental Borderland: Geological Society of America Special Paper 454, p. 171-192.

Yerkes, R.F., Wagner, H.C., and Yenne, K.A., 1969, Petroleum development in the region of the Santa Barbara Channel: U.S. Geological Survey Professional Paper 679-B, p. 11-21. 